Mercer University School of Law

Mercer Law School Digital Commons

2018

Quacks or Bootleggers: Who's Really Regulating Hedge Funds?

Jeremy Kidd

Mercer University School of Law, kidd_j@law.mercer.edu

Follow this and additional works at: https://digitalcommons.law.mercer.edu/fac_pubs

Part of the Administrative Law Commons, Banking and Finance Law Commons, and the Business Organizations Law Commons

Recommended Citation

Jeremy Kidd, Quacks or Bootleggers: Who's Really Regulating Hedge Funds?, 75 Wash. \& Lee L. Rev. 367 (2018).

This Article is brought to you for free and open access by the Faculty at Mercer Law School Digital Commons. It has been accepted for inclusion in Faculty Publications by an authorized administrator of Mercer Law School Digital Commons. For more information, please contact repository@law.mercer.edu. 


\title{
Quacks or Bootleggers: Who's Really Regulating Hedge Funds?
}

\author{
Jeremy Kidd, J.D., Ph.D.*
}

\begin{abstract}
Influential scholars of corporate law have questioned previous federal interventions into corporate governance, calling it quackery. Invoking images of medical malpractice, these critiques have argued persuasively that Congress, in responding to crises, makes policy that disrupts efficient private rules and established state laws. This Article applies the Bootleggers and Baptists theory to show that Dodd-Frank's hedge fund rules are more than just negligent or reckless, but designed to benefit special interests that compete with the hedge fund model. Those rules offer no solutions to any real or perceived risks arising from hedge fund investing, but might offer an advantage to competitors of hedge funds.
\end{abstract}

\section{Table of Contents}

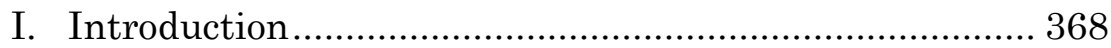

II. The Quackery Critique ................................................. 372

A. Quacks in SOX .................................................... 373

1. The Snake Oil................................................... 375

2. The Salesmen ................................................... 378

B. Dodd-Frank Also Quacks.................................. 380

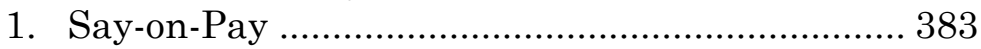

2. Independent Compensation Committees............ 385

3. Expanded Clawback Provisions ......................... 385

* Associate Professor of Law, Mercer University Walter F. George School of Law. Thanks to helpful comments from Roberta Romano, Michelle Harner, Paul Stancil, Christine Hurt, and the attendees of the 2016 J. Reuben Clark Faculty Conference and 2016 Federalist Society Faculty Conference Works In Progress panel. 
4. Shareholder Access Rule .................................. 386

5. Disclosure Requirements............................... 387

6. The Salesmen .................................................... 389

C. The Quackery Hypothesis ....................................... 391

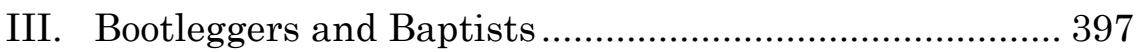

A. Bootlegger Theory.................................................. 401

1. What's in it for the Baptist? .............................. 402

2. What's in it for the Bootlegger?.......................... 404

3. What's in it for the Regulator? .......................... 406

B. How to spot a Bootlegger ...................................... 411

C. Bootleggers or Quacks? .......................................... 413

IV. What is a Hedge Fund?............................................... 414

V. The Great Recession and the Birth of Dodd-Frank...... 416

A. Overarching Goals .............................................. 417

B. Criticism in the 111th Congress ........................... 418

C. From Criticizing to Legislating .............................. 426

1. Action in the House............................................ 428

2. Meanwhile, in the Senate................................ 429

VI. Who is Dodd-Frank Protecting? ................................... 434

A. Investors................................................................. 435

B. Public ..................................................................... 437

VII. Bootleggers in Dodd-Frank .......................................... 441

A. What Would Big Finance Gain?............................. 443

B. Intra-Industry Conflict? ....................................... 445

C. Any Other Bootleggers Hiding? .............................. 446

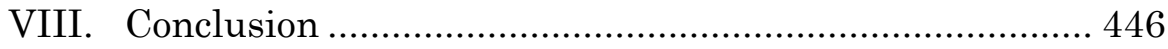

\section{Introduction}

On February 3, 2017, President Donald Trump issued an executive order, entitled "Core Principles for Regulating the United States Financial System,"1 described by then Press Secretary Sean Spicer $^{2}$ as part of an intended effort to rescind some

1. Exec. Order No. 13,772, 82 Fed. Reg. 9,965 (Feb. 3, 2017).

2. See Press Briefing by Press Secretary Sean Spicer, 2/3/2017, \#8, White 
of the provisions of the Dodd-Frank Wall Street Reform and Consumer Protection Act (Dodd-Frank). ${ }^{3}$ Dodd-Frank is viewed by many as "a disastrous policy" 4 for our financial markets and our economy, but what makes it disastrous? Professor Stephen Bainbridge has argued that Dodd-Frank's corporate governance regime is quackery, an ineffective remedy that could even cause harm. ${ }^{5}$ This paper argues that the quackery may extend to DoddFrank's hedge fund regulations, as well. The paper then goes one step further and argues that things may be even worse, that DoddFrank's regulatory regime may be the work of bootleggers. ${ }^{6}$

Quackery would be bad enough, as the term conjures images of bloodletting, lobotomies, leeches, glysters, ${ }^{7}$ and the like. These were all once respected medical practices, yet the passage of time has revealed that they were not only useless as medical remedies, but often far more likely to kill or injure the patient than the apparent malady being "cured." ${ }^{8}$ Other supposed remedies-snake

House OfF. PREss SEC'Y (Feb. 3, 2017, 12:37 PM), https://www.whitehouse.gov/briefings-statements/press-briefing-press-secretarysean-spicer-020317/ (last visited Feb. 17, 2018) [hereinafter Press Briefing] ("Dodd-Frank has been both a disaster in terms of the impact that it's had, but also it hasn't achieved the goal ... I think we're going to continue not just to act through administrative action, but through working with Congress and figuring out a legislative fix.") (on file with the Washington and Lee Law Review).

3. Dodd-Frank Wall Street Reform and Consumer Protection Act, Pub. L. No. 111-203, 124 Stat. 1376 (2010) [hereinafter "Dodd-Frank"].

4. See Press Briefing, supra note 2 ("The Dodd-Frank Act is a disastrous policy that's hindering our markets, reducing the availability of credit, and crippling our economy's ability to grow and create jobs.”).

5. See Stephen M. Bainbridge, Dodd-Frank: Quack Federal Corporate Governance Round II, 95 MinN. L. REV. 1779, 1783 (2011) ("Dodd-Frank is to corporate governance as quackery is to medical practice."). Bainbridge adopts the language used by Roberta Romano in describing Sarbanes-Oxley as "quack corporate governance" in her Article titled, The Sarbanes-Oxley Act and the Making of Quack Corporate Governance, 114 YALE L.J. 1521 (2005) [hereinafter Romano, Making of Quack Corporate Governance].

6. See Bruce Yandle, Bootleggers and Baptists-The Education of a Regulatory Economist, REGULATION, May-June 1983, at 12, 13 [hereinafter Yandle, Bootleggers and Baptists] (describing Bootleggers and Baptists theory).

7. A glyster involved the use of a bellows to introduce tobacco smoke into the lower bowels of the patient. Michael C. Munger, The Thing Itself: Essays ON ACADEMICS AND THE STATE 4 (2015).

8. See id. ("Not surprisingly, people thought that fevers were deadly, and to be fair, fevers really were deadly ... if someone panicked and called a doctor to 
oil, ${ }^{9}$ miracle salves, ${ }^{10}$ etc. - - have always been recognized for the frauds that they are by most individuals in the United States. These forms of quack medicine seem absurd today, yet many homeopathic remedies without any evidence of effectiveness continue to plague desperate patients seeking a cure for what ails them. ${ }^{11}$

The same can also be said of much of our legal and regulatory regime. Bainbridge and Romano argue that federal attempts at regulating corporate governance, an issue normally left to state legislatures and courts, shares the characteristics of quack medicine. ${ }^{12}$ There are reasons to be skeptical of the effectiveness of federal regulation, particularly as responses to crises when political pressures are high and a sense of caution may be a political liability. ${ }^{13}$ Whether acting on their own mistaken theories or those of outside "experts," solutions crafted in the wake of a major economic or political event are likely to have the

do something.").

9. See Lakshmi Gandhi, A History of 'Snake Oil Salesmen,' NPR: CoDE SwITCH (Aug. 26, 2013, 11:55 AM), http://www.npr.org/sections/codeswitch/ 2013/08/26/215761377/a-history-of-snake-oil-salesmen (last visited Feb. 17, 2018) (noting that snake oil was effective in China but became a symbol of fraud when entrepreneur Clark Stanley attempted to introduce replicate oils to the United States) (on file with the Washington and Lee Law Review).

10. See Ben Tinker, FDA Cracks Down on 'Illegal' Cancer Treatments, CNN, http://www.cnn.com/2017/04/25/health/cancer-treatments-illegal-fraudulentmisleading-fda/index.html (last updated Apr. 25, 2017, 10:00 PM) (last visited Feb. 17, 2017) (listing Hawk Dok Natural Salve LLC, a company that claims it found a natural way to fight cancer and HPV, as one that received a warning letter from the FDA because the product could be unsafe and/or prevent someone from seeking life-saving treatment) (on file with the Washington and Lee Law Review).

11. See id. (referring to the fear and desperation that may tempt individuals to try a product that claims to cure a disease, but that "if something seems too good to be true, it probably is").

12. See Bainbridge, supra note 5, at 1801 (referring to the "unique foibles of Dodd-Frank's provisions" and the Sarbanes-Oxley Act of 2002 as quack corporate governance (citing Roberta Romano, The Sarbanes-Oxley Act and the Making of Quack Corporate Governance, 114 YALE L.J. 1521 (2015))).

13. See id. at 1794 ("[U]nlike state law, federal intrusions typically have resulted in quack corporate governance. We have already seen three reasons why this is so persistently the case. First, federal bubble laws tend to be enacted in a climate of political pressure that does not facilitate careful analysis of costs and benefits."). 
characteristics of quackery. ${ }^{14}$ Legislators and regulators might prescribe the legal version of a glyster or bloodletting, making the patient-the U.S. economy-even worse off than the crisis itself.

When it comes to hedge fund regulation under Dodd-Frank, the metaphor may also apply. The regime addresses a minor-to-nonexistent problem and does so in a way virtually guaranteed to do nothing to remedy any perceived problems..$^{15}$ Applying Bruce Yandle's Baptists and Bootlegger theory, ${ }^{16}$ the Article questions whether the impending "failure" of Dodd-Frank is by design. Specifically, the Article investigates how the very provisions that guarantee failure of the regime's stated goals might be perfectly designed to achieve more subtle goals of certain powerful-but-hidden interests. ${ }^{17}$ In other words, whether hedge fund regulations were designed by well-intentioned but incompetent quacks or sophisticated, rent-seeking bootleggers.

Section II will review the quackery metaphor as introduced by Romano and Bainbridge and then generalize its terms. ${ }^{18}$ Section III will then discuss the Bootleggers and Baptists theory and how it explains government regulation that fails its stated goals but may achieve additional, unstated ones. ${ }^{19}$ The rest of the Article will then analyze the regulation of hedge funds under Dodd-Frank. Section IV will briefly describe how hedge funds fit within financial markets, ${ }^{20}$ followed in Section V by a discussion of how Dodd-

14. See Romano, Making of Quack Corporate Governance, supra note 5, at 1528 (regarding Sarbanes-Oxley Act as an "emergency legislation, enacted under conditions of limited legislative debate, during a media frenzy involving several high-profile corporate fraud and insolvency cases... in conjunction with an economic downturn, [and] what appeared to be a free-falling stock market").

15. See Bainbridge, supra note 5, at 1821 ("A powerful interest group coalition centered on activist institutional investors hijacked the legislative process so as to achieve longstanding policy goals essentially unrelated to the causes or consequences of the financial crisis that began back in 2007.").

16. See Yandle, Bootleggers and Baptists, supra note 6, at 13 (describing Bootleggers and Baptists theory).

17. See infra Part III.A (analogizing the Bootlegger prong of the Bootleggers and Baptists theory with Dodd-Frank, whereby regulation addressing a failure can also benefit private interests).

18. See infra Part II (describing the Bootleggers and Baptists theory and extrapolating general principles).

19. See infra Part III (connecting general principles in Part II to regulation).

20. See infra Part IV (providing financial background for the remainder of 
Frank and its regulation of hedge funds came to be. ${ }^{21}$ Section VI then takes a critical look at whether Dodd-Frank's goals have been-or even can be-achieved through its regulation of hedge funds. ${ }^{22}$

After concluding that Dodd-Frank stands little chance of achieving its public goals, Section VII applies the Bootlegger and Baptist theory to identify those third parties who might benefit from the particular regulatory regime adopted by Dodd-Frank: large traditional investment houses who stand to gain by removing a competitive advantage previously enjoyed by the now-regulated hedge funds; and larger hedge funds who can more effectively defray compliance costs than their smaller competitors. ${ }^{23}$ Concluding thoughts and ideas for further inquiry are then offered in Section VIII. ${ }^{24}$

\section{The Quackery Critique}

Quacks, like confidence men, are different from thieves because the victim voluntarily hands over whatever the quack or con man requests. ${ }^{25}$ It is even possible that the quack believes his own marketing. ${ }^{26}$ Irrespective of the intent of the quack or con

the Article).

21. See infra Part V (outlining the origins on Dodd-Frank).

22. See infra Part VI (looking at the effectiveness, or lack thereof, of regulation attempting to actualize Dodd-Frank's purpose).

23. See infra Part VII (applying the Bootleggers and Baptists theory to Dodd-Frank).

24. See infra Part VIII (summarizing the Article's conclusions and areas for further analysis).

25. See Jean Braucher \& Barry Orbach, Scamming: The Misunderstood Confidence Man, 27 J.L. \& HumAN. 249, 250 (2015) ("The trusting victim literally thrusts a fat bank roll into [the confidence man's] hands. It is a point of pride with him that he does not have to steal." (quoting DAvid MAURER, THE BIG CON 1 (1940))).

26. One author proposes three types of quacks: (1) the "dumb quacks" who know nothing about the remedies they are creating but persist in their creating; (2) the "deluded quacks" whose medical knowledge is limited and whose observations and conclusions are flawed; and (3) the "dishonest quacks" who know they are perpetrating a fraud but care more for the money they make. Note, Quackery in California, 11 STAN. L. REV. 265, 267 (1959). 
man, there is still harm caused; the victim of a con is fraudulently deprived of something of value and a patient who receives treatment from a quack pays for non-treatment and may even delay real care until it is too late. ${ }^{27}$ Those likely to be taken in by con men and quacks are typically those with little faith in traditional methods and desperate for a miracle. ${ }^{28}$ They are more likely to be easily distracted by grand promises and sophisticated explanations for why traditional methods will fail. ${ }^{29}$ While sham remedies in the medical field may have dwindled since the nineteenth century, ${ }^{30}$ they appear to be ascendant in the regulatory field, particularly with regard to financial regulation and corporate governance. ${ }^{31}$ Two prominent examples are the Sarbanes-Oxley Act of 2002 32 (SOX) and Dodd-Frank.

\section{A. Quacks in $S O X$}

Congress passed Sarbanes-Oxley in the aftermath of the Enron and Worldcom debacles and in the lead up to the 2002

27. See, e.g., Katharine A. Van Tassel, Slaying the Hydra: The History of Quack Medicine, the Obesity Epidemic and the FDA's Battle to Regulate Dietary Supplements Marketed as Weight Loss Aids, 6 InD. HeALTH L. REV. 203, 213 (2009) (describing how obese individuals forego beneficial lifestyle changes and treatments because they believe a weight loss supplement will resolve their weight issues). But see W. John Thomas, Informed Consent, The Placebo Effect, and the Revenge of Thomas Percival, 22 J. Legal Med. 313, 313-15 (2001) (relating anecdotes of terminal patients whose lifespans were incredibly extended because they believed in the curative effects of placebos).

28. See, e.g., Van Tassel, supra note 27, at 205 ("Overweight consumers desperate to lose weight are being lured by 'magic bullet' claims into purchasing 'quick-fix' weight lost supplements in order to lose weight and decrease their risk for disease.").

29. See, e.g., Quackery in California, supra note 26, at 267 (referring to a quack's victim as "hopeless" because proven medical aid is insufficient, or "miracle seekers, who are taken in by glittering promises").

30. See Van Tassel, supra note 27, at 219 ("[T] he nineteenth century was known as the "grand era of the quack remedy." (quoting PHILIP J. HILTs, Protecting America's Health: The FDA, Business, and One HundRed Years of REGULATION 23 (2003))).

31. See generally Romano, Making of Quack Corporate Governance, supra note 5 (referring to the Sarbanes-Oxley Act of 2002 as quack governance in her title).

32. Pub. L. No. 107-204, 116 Stat. 745 (2002). 
mid-term elections. ${ }^{33}$ It was a large and complicated piece of legislation and included, among other things, numerous provisions related to corporate governance, ${ }^{34}$ including some that changed the boundaries of separation between federal and state regulation of corporations. ${ }^{35}$ Shifting the balance of power in corporate governance regulation by way of substantive rules was both unnecessary and wasteful because the substantive rules could have been formulated as disclosure requirements, traditionally within the realm of federal law. ${ }^{36}$ Doing so would have maintained the existing balance between federal and state regulation and limited the significant increases in costs of compliance. ${ }^{37}$

It is possible for laws to be enacted and regulations to be promulgated in error, especially in the wake of a crisis and even more so in an election year, as every politician will feel pressure to do something-however ill-advised that something might be. ${ }^{38}$

33. Both companies entered bankruptcy proceedings after revelations that they engaged in fraudulent accounting practices and self-dealing by executives. Romano, Making of Quack Corporate Governance, supra note 5, at 1523.

34. See id. at 1527 (noting that various provisions required corporations to establish independent audit committees, restricted their purchasing non-auditing services from the firms hired to perform audits, prohibited loans to corporate officers, and mandated that executives certify financial statements).

35. See id. ("[T] he substantive corporate governance provisions overstep the traditional division between federal and state jurisdiction, although they did not have to do so."). Given the crisis in which it emerged, it is not surprising that Sarbanes-Oxley also included items that were completely unrelated to the perceived crisis, such as the Bipartisan Campaign Finance Reform Act of 2002, Pub. L. No. 107-155, 2002 U.S.C.C.A.N. (116 Stat.) 81 (to be codified in scattered sections of 2 and 26 U.S.C.).

36. See Romano, Making of Quack Corporate Governance, supra note 5, at 1528 (calling the choice of regulatory form under Sarbanes-Oxley "more costly"). Professor Romano turned out to be correct. See Joseph A. Grundfest \& Steven E. Bochner, Fixing 404, 105 MicH. L. REV. 1643, 1645-46 (2007) ("First-year implementation costs for larger companies were thus eighty times greater than the SEC had estimated, and sixteen times greater than estimated for smaller companies.").

37. See Bainbridge, supra note 5, at 1781 ("When SOX was adopted neither Congress nor the Securities and Exchange Commission (SEC) appreciated just how costly it would prove ... . The direct cost of complying with section 404 in its first year [was] $\$ 7.3$ million for large accelerated filers and $\$ 1.5$ million for accelerated filers."). 1600

38. See Romano, Making of Quack Corporate Governance, supra note 5, at 
What made Sarbanes-Oxley particularly troubling, however, is that the proposed changes were known to stand very little chance of success. ${ }^{39}$

\section{The Snake Oil}

As cataloged by Romano, ${ }^{40}$ what was known about these proposals weighed heavily against any likelihood of success. On the requirement of independent audit committees, ten out of sixteen then-existent studies on the subject found no link between independence of audit committees and performance of those committees. ${ }^{41}$ This is in keeping with the consensus that independent boards, generally, do not improve performance and might even have a negative impact. ${ }^{42}$ More importantly, the one factor that was known at the time to have a positive impact on audit committee performance-having a committee member with financial expertise-was not mandated by Sarbanes-Oxley. ${ }^{43}$ In

Congress cannot be expected to take no action in times of financial exigency given the election cycle. Retaining one's public office is an understandably powerful motivating force, and financial crises are often accompanied by a media frenzy... that plays into public discontent and generates expectations of government solutions.

39. See id. at 1585 ("The contention from a symbolic politics perspective is that despite the mandates' known probable ineffectiveness, their enactment provided an expressive or symbolic benefit: Congress's demonstration to a concerned public that it was remedying a serious problem.").

40. See id. at 1529-43 (describing the main SOX mandates).

41. Id. at 1532 .

42. See id. at 1530 ("[I]ndependent boards do not improve performance and ... boards with too many outsiders may, in fact, have a negative impact on performance."); see also Sanjai Bhagat \& Bernard Black, The Uncertain Relationship Between Board Composition and Firm Performance, 54 Bus. LAW. 921, 942-45 (1999) (summarizing the literature on Board independence and firm performance); Julie Cotter \& Mark Silvester, Board and Monitoring Committee Independence, ABACUS, June 2003, at 211, 228-29 (finding no relation between independent audit committees and firm performance).

43. See Romano, Making of Quack Corporate Governance, supra note 5, at 1532 ("[C]omplete independence is less significant than [financial] expertise with respect to the relation between audit committee composition and accounting statement quality. These results are notable in that SOX does not mandate the presence of a financial expert on the audit committee."). 
other words, a possible cure was ignored while Congress mandated a remedy that had no empirical foundation.

This same pattern holds true for other substantive changes. Sarbanes-Oxley banned the purchase of certain non-audit services from the same firm that was conducting the audit. ${ }^{44}$ However, fifteen of twenty-five studies to address the question found no connection between purchase of non-audit services and the quality of the audit, and three found that the quality of the audit is actually improved when non-audit services are purchased.45 Moreover, the studies that found no connection also used the most sophisticated techniques and were the most robust, ${ }^{46}$ improving the confidence that an objective observer would have in trusting those conclusions and rejecting the claims of Sarbanes-Oxley proponents.

Sarbanes-Oxley also banned extension of credit by corporations to their executives, a provision that played well for Congress and the public. ${ }^{47}$ In reality, this was a single tool of many that corporations used to compensate their officers and directors,

44. Pub. L. No. 107-204, § 201.

45. Romano, Making of Quack Corporate Governance, supra note 5, at 153536. One study found no connection as long as the auditing firm was one of the Big Five accounting firms. Id. at 1536. But see Richard M. Frankel et al., The Relation Between Auditors' Fees for Nonaudit Services and Earnings Management, 77 ACCT. REV. 71, 100 (2002) (finding a negative relationship between purchase of non-audit services and quality of the audit). However, as noted by Romano, Making of Quack Corporate Governance, supra note 5, at 1537, subsequent studies have cast doubt on the validity of the Frankel study. Ribstein also points out that this provision reduces the incentive to use large auditing firms who can offer a wide range of services and who-not coincidentally-have far more to lose if they engage in unethical behavior. See Larry Ribstein, Bubble Laws, 40 Hous. L. REV. 77, 88 (2003) ("[I]ncreasing auditor independence may reduce their access to information as well as their expertise, ability and incentives."). This provision could actually increase the amount of bad behavior by auditors.

46. See Romano, Making of Quack Corporate Governance, supra note 5, at 1537 (claiming that this conclusion is not only compelling "because it is the finding of the vast majority of studies but also because it is the result of the studies using the most sophisticated techniques, as well as those whose findings are most robust to alternative model specifications"). This was also true of those studies that found no connection between independence of the audit committee and the outcome of the audit. See id. at 1533 (concluding that these studies are also compelling and used sophisticated techniques).

47. See id. at 1538 ("Section 402(a) of SOX prohibits corporations from arranging or extending credit to executive officers or directors.”). 
and taking away compensation tools makes the already complicated job of crafting an efficient compensation package even harder. ${ }^{48}$ Because corporations must compete in the market for corporate executives, they will craft a compensation package that achieves the desired end-optimum corporate performance, for example-at the lowest possible cost. ${ }^{49} \mathrm{~A}$ rule that bans the use of specific compensatory tools is guaranteed to increase the total cost of compensation. ${ }^{50}$ Prior to Sarbanes-Oxley, the practice of extending credit to executives-often so that executives could purchase corporate stock-was thought unobjectionable so there was no empirical research on its effect. ${ }^{51}$ One study was conducted in the wake of Sarbanes-Oxley, and the results were consistent with the conventional wisdom that this practice was designed to improve alignment of managers' and shareholders' incentives. ${ }^{52}$

Sarbanes-Oxley also required that executives certify financial statements, although this was not entirely new, ${ }^{53}$ and the data is inconclusive regarding its effectiveness. ${ }^{54}$ Note, however, that of

48. See id. ("The blanket prohibition has engendered concern among practitioners, because it appears to prohibit standard compensation practices thought to be uncontroversial and beneficial, such as the purchase of split-dollar life insurance policies.").

49. See, e.g., Henry N. Butler, The Contractual Theory of the Corporation, 11 Geo. Mason U. L. REV. 99, 117-18 (1989) (describing the factors that influence compensation packages).

50. See Romano, Making of Quack Corporate Governance, supra note 5, at 1538-39 (claiming that when "one form of compensation is restricted ... [i]nvestors have to increase another component of the manager's pay package to make up the loss in utility from the removal of the now-restricted compensation option").

51. See id. at 1539 (stating that extension of credit to corporate officers was not a contentious topic).

52. See id. at 1539 ("There is an increase in executives' equity ownership after the extension of credit to purchase stock or to exercise stock options, although the increase is small relative to loan value." (referring to the study found in Kuldeep Shastri \& Kathleen M. Kahle, Executive Loans, 39 J. FIN. \& QUANTITATIVE ANALYSIS 791 (2004))).

53. See Lisa M. Fairfax, Form over Substance?: Officer Certification and the Promise of Enhanced Personal Accountability Under the Sarbanes-Oxley Act, 55 RUTGERS L. REV. 1, 20-42 (2002) (discussing pre-SOX law on executive certification of financial statements).

54. See Romano, Making of Quack Corporate Governance, supra note 5, at 1541-42 (stating that the results of two relevant studies are inconsistent); see also Beverly Hirtle, Stock Market Reaction to Financial Statement Certification by 
the four major changes to corporate governance, this is the best that can be said-the empirical data is inconclusive. In other words, there is no firm data that the applied remedy had any positive impact. For the remaining three changes, the empirical results show-and in some cases showed at the time SarbanesOxley was being debated-that there was never any real chance of the remedy actually fixing anything. ${ }^{55}$ In at least one case, a remedy was available that could potentially have improved the situation, but that was ignored. ${ }^{56}$

\section{The Salesmen}

Why did this happen? Romano documents the names and something of the motivations of individuals she refers to as "policy entrepreneurs," 57 those who pushed for these proposals. ${ }^{58}$ Another name for these individuals would be "quacks," regulatory snake-oil salesmen peddling remedies with no hope of success to a Congress desperate for a solution-any solution-that would cure their electoral ills. ${ }^{59}$

In some cases, they had been peddling their remedies for some time. For example, there had been proposals to require independent audit committees and prohibit purchase of non-audit services from auditors before the Enron and Worldcom debacles. ${ }^{60}$

Bank Holding Company CEOs, 38 J. Money, CREDIT \& BANKING 1263, 1273 (2006) (finding a positive correlation between certification and firm performance); Utpal Bhattacharya, Peter Groznik \& Bruce Haslem, Is CEO Certification of Earnings Numbers Value-Relevant?, 14 J. EMPIRICAL FIN. 611, 611 (2007) (finding no effect from certification).

55. See Romano, Making of Quack Corporate Governance, supra note 5, at 1585 (arguing that it was more symbolic than effective).

56. See id. at 1532 (requiring a financial expert on the audit committee is proven to be successful, but was not mandated).

57. Id. at 1568 .

58. See id. at 1568-85 (describing the background motivation for the proposals).

59. This is particularly the case for Republican members of Congress, for whom this type of national corporate regulation is typically disfavored, but who needed a way to defuse an electoral time bomb. See id. at 1564-68 (explaining why Republicans voted for the bill).

60. See id. at 1523-24 ("In particular, the independent-director requirement 
These proposals had not been adopted, perhaps because the conditions were not right for such a substantial shift in power to regulate corporations. ${ }^{61}$ Only the advent of the Enron and Worldcom scandals made the public so insistent on finding a "cure" that Members of Congress became desperate enough to buy the snake oil without making some basic inquiries. ${ }^{62}$ For example, the existing empirical research was never discussed. ${ }^{63}$ The complete absence of any state regulations along the proposed lines-even though competition between states should have incentivized

and the prohibition of accounting firms' provision of consulting services to auditing clients had been advanced as needed corporate law reforms long before Enron appeared on any politician's agenda."); see also Stephen M. Bainbridge, A Critique of the NYSE's Director Independence Listing Standards, 30 SEC. REG. L.J. 370, 377-81 (2002) (comparing Sarbanes-Oxley rules to ALI corporate governance projects from the 1980s); Subcomm. on Reports, Accounting, \& Mgmt. of the Senate Comm. on Governmental Affairs, 95th Cong., Improving the Accountability of Publicly Owned Corporations and Their Auditors (Comm. Print 1977) (considering a proposal to separate auditing from non-auditing services; Revision of the Commission's Auditor Independence Requirements, 65 Fed. Reg. 76,008 (Dec. 5, 2000) (codified at 17 C.F.R. $\S \S 210.1-02,240.14 a-101$ (2004)); Audit Committee Disclosure, Exchange Act Release No. 34-42,266, 64 Fed. Reg. 73,389 (Dec. 30, 1999) (codified in scattered sections of 17 C.F.R. pts. 210, 228-29, 240 (2004)).

61. See Romano, Making of Quack Corporate Governance, supra note 5, at 1524 ("[S] uccessful law reform in the national arena typically involves the recombination of old elements that have been advanced in policy circles for a number of years prior to adoption."). Some political scientists have identified three factors that typically accompany major shifts: shifts in national mood; turnover of elected officials; and events that focus public attention. See JoHN W. Kingdon, Agendas, Alternatives, And Public Policies 20-21, 170-72, 206-08 (1984) (noting that these three factors open the way for policy entrepreneurs to enact policies that would be improbable, at best, any other time); $f$. Todd Zywicki \& Jeremy Kidd, Meaningful Tort Reform: A Public Choice Analysis 44-45 (Feb. 11, 2010) (unpublished manuscript) (describing different factors and circumstances increasing the potential for lasting reform).

62. See Romano, Making of Quack Corporate Governance, supra note 5, at 1525 ("[I]t was widely perceived . . . that members of Congress were motivated by reelection concerns when a statute was hurriedly enacted in the summer prior to the midterm elections, after months of languishing in committee, following heightened attention on corporate malfeasance as the WorldCom scandal erupted post-Enron.").

63. See id. at 1563 (noting that "empirical research was accorded little weight in the setting of regulation"). 
movement towards more efficient corporate governance rules ${ }^{64}$ was never mentioned.

\section{B. Dodd-Frank Also Quacks}

According to Bainbridge, the quackery in Sarbanes-Oxley is the rule in corporate governance regulation, rather than the exception. ${ }^{65}$ "In a pattern that can be traced back at least to England in the late 1600 s, major new corporate regulation has tended to follow market turmoil."66 Bainbridge labels these laws "bubble laws" because it is only in the crisis atmosphere that follows a bubble bursting that quacks find Congress desperate enough to buy snake oil remedies for real or imagined problems. ${ }^{67}$

64. See Ralph K. Winter, Jr., State Law, Shareholder Protection, and the Theory of the Corporation, 6 J. LEGAL STUD. 251, 254-58 (1977) (describing a "race to the top" in corporate governance rules as a result of competition between states); Ralph K. Winter, The "Race for the Top" Revisited: A Comment on Eisenberg, 89 COLUM. L. REV. 1526, 1528-29 (1989) ("States that offer such impediments to takeovers may thus attract some chartering business. Of course, ... the purpose of impediments to takeovers is precisely to reduce the discipline of the capital market and that may well seem attractive to inefficient managers."). But see William L. Cary, Federalism and Corporate Law: Reflections upon Delaware, 83 YALE L.J. 663, 666 (1974) (describing a "race to the bottom").

65. See Bainbridge, supra note 5, at 1782 ("SOX was not a one-off event. To the contrary, it was a fairly standard example of the boom-bust-regulate pattern that characterizes U.S. federal regulation of corporate governance.").

66. Id.; see also Ribstein, supra note 45, at 83 (arguing that regulation in the wake of the 1929 crash and the South Sea Bubble of the early 1700s followed the same pattern).

67. See Bainbridge, supra note 5, at 1786 ("It is in the post-bubble environment, 'when scandals and economic reversals occur' and 'when corporate transactions grab the attention of the American public and the U.S. Congress,' that Congress often acts."). Bainbridge borrows the term "bubble laws" from Ribstein who diagnoses the general political, economic, and cultural trends that accompany the boom and bust cycle and lead to over-regulation and a willful blindness to the relative costs and benefits of that regulation. Ribstein, supra note 45, at 79-83. Ribstein argues that regulation in the wake of a market crisis-a bust-is not cost effective for four reasons: first, the bust removes the blinders from investors' eyes, making future fraud less likely; second, to the extent investors will be fooled in future booms, regulation will not be able to pierce the haze of overly optimistic expectations; third, fraud in future booms will be different so regulations based on past frauds are useless; and fourth, those formulating regulations in the wake of a bust will ignore the costs of compliance, so regulations are likely to be grossly inefficient. See id. at 81-82 (explaining why 
These laws-ostensibly presented as "reforms"-share common characteristics: they are passed in a hurry, largely from ready-made policy packages that were pushed long before the crisis, and they penalize or prohibit useful practices, or they discourage risk-taking by punishing negative results. ${ }^{68}$ Stated more formally, Bainbridge states that quack corporate governance regulation shares eight characteristics: (1) it is passed in the wake of a negative economic event; (2) it is enacted in a crisis environment; (3) it is a response to a backlash against corporations and markets; (4) it is federal, rather than state regulation; (5) it transfers power from the states to the federal government; (6) it is supported by interest groups that have more influence at the national level; (7) it is a long-standing project of a powerful interest group; and (8) the empirical evidence is, at best, uncertain and, at worst, indicative of a likelihood of harm. ${ }^{69}$

The first three characteristics define the circumstances in which a victim of quackery is likely to abandon reason and buy the sham remedy. The American public, represented by its government, sees itself in dire need and has identified-rightly or wrongly - corporations and markets as the source of its affliction. The last two characteristics define the remedy, which comes ready for sale. This is no thoughtful diagnosis and carefully designed remedy; the remedy was mixed long ago and any crisis would have sufficed to motivate the interest groups' sales pitch. ${ }^{70}$ The lack of credible evidence that the remedy will cure the supposed ailments is the defining characteristic of quackery. ${ }^{71}$ The fourth, fifth, and

regulation in the aftermath of a financial crisis is not cost effective).

68. See Bainbridge, supra note 5, at 1786-87 (explaining the characteristics of bubble laws).

69. See id. at 1796 (listing commonalities among quack corporate governance regulation).

70. See id. at 1786 ("[T]ime tends to give advantages to interest groups and other policy entrepreneurs who have prepackaged purported solutions that can be readily adapted into legislative form. Hence, for example, many of SOX's provisions were 'recycled ideas' that had been 'advocated for quite some time by corporate governance entrepreneurs."').

71. It is conceivable that some may prefer punishment of corporations as an end to itself, and it is possible to fear risk-taking to such an extent that punishment and elimination of all risk could be seen as "successes." Bainbridge and Romano assume a world where punishment for its own sake and elimination 
sixth characteristics have more to do with a preference for federal regulation over state regulation, rather than the nature of the regulation as quackery. ${ }^{72}$

Does Dodd-Frank qualify as quackery? Like Sarbanes-Oxley, Dodd-Frank was a huge, complex piece of legislation and most of its 2,319 pages were not focused on corporate governance. ${ }^{73}$ Bainbridge, however, identifies six provisions of Dodd-Frank that fit his definition of quackery: (1) the say-on-pay mandate; (2) the requirement that compensation committees be independent; (3) additional disclosure requirements for executive compensation; (4) expanded clawbacks of executive compensation; (5) express authority for the Securities and Exchange Commission's (SEC) shareholder access rule; and (6) disclosure requirements for whether a single person serves as Chairman and CEO. ${ }^{74}$ Some provisions are a benign form of quackery, presenting nothing more than "meaningless symbolism," but others are more poisonous tonics, imposing significant risks. ${ }^{75}$ All are quackery, however, because they offer no realistic chance of limiting systemic risk or future financial crises.

of all risk are acceptable or desirable goals, so it is possible to imagine a world where these regulations do have a significant chance of success under those limited criteria. However, most policy debates do not expressly list punishment of all corporations and elimination of all risk as the goals; instead, it is typically argued that the goals are merely to punish wrongdoing and avoid "systemic" risk. See, e.g., Julie A.D. Manasfi, Systemic Risk and Dodd-Frank's Volcker Rule, 4 WM. \& MARY BUS. L. REV. 181, 184 (2013) ("With the recent global financial crisis starting in 2007, the issue of 'systemic risk' has been front and center in our political discourse.").

72. There are legitimate arguments on both sides of this debate, as can be seen in Romano, Making of Quack Corporate Governance, supra note 5, at 152324 , but that debate is beyond the limited scope of this Article.

73. See Bainbridge, supra note 5, at 1783 ("Although Dodd-Frank's 2,319 pages dwarf SOX in both size and scope, most of the Act deals with issues other than corporate governance.").

74. See id. at 1783 (describing how Dodd-Frank is characteristic of quackery).

75. See id. at $1783,1797-1815$ (arguing that some of Dodd-Frank's six provisions are meaningless symbolism but that others are likely to have serious adverse consequences). 


\section{Say-on-Pay}

The motivation for say-on-pay was the perception that corporate executives not only made too much, but that their pay was uncoupled from the performance of their companies. ${ }^{76}$ Excessive and uncoupled compensation is allegedly the result of executives' capturing the boards that decide their pay, ${ }^{77}$ allowing executives to reap the rewards of their positions regardless of how well they do their job. A review of the evidence shows this assertion to be highly questionable, as it has occurred while board independence has increased, CEO tenure has decreased, and accounting practices have become more transparent. ${ }^{78}$ Also, executive pay has risen dramatically, but no less dramatically than the wealth of shareholders, as market capitalization of corporations has risen equivalent to executive pay. ${ }^{79}$

Even if there is no crisis in executive compensation, that does not mean that a change like say-on-pay might not have a positive impact. Some observers argue that the British experiment with say-on-pay indicates reason to hope that it will have a positive impact on U.S. corporate governance. ${ }^{80}$ Others, however, point out

76. See id. at 1808 ("As the Senate committee put it, "the economic crisis revealed instances in which corporate executives received very high compensation despite the very poor performance by their firms." (quoting S. REP. No. 111-176, at $133(2010)))$.

77. Id. (quoting Lucian Bebchuk \& Jesse Fried, Pay Without Performance: The Unfulfilled Promise of Executive Compensation 5-6 (2004)).

78. See id. at 1809-10 (providing a glimpse of the immense literature on the topic); see also Franklin G. Snyder, More Pieces of the CEO Compensation Puzzle, 28 DEL. J. CORP. L. 129, 133 (2003) (arguing that under the managerial power approach, increase in CEO compensation, increase in board independence, and declines in CEO tenure should not happen).

79. See Xavier Gabaix \& Augustin Landier, Why Has CEO Pay Increased So Much?, 123 Q.J. ECON. 49, 50 (2008) ("Historically, in the U.S. at least, the rise of CEO compensation coincided with an increase in market capitalization of the largest firms.").

80. See, e.g., Protecting Shareholders and Enhancing Public Confidence by Improving Corporate Governance: Hearing Before the Subcomm. on Sec., Ins., \& Inv. of the S. Comm. on Banking, Hous., and Urban Affairs, 111th Cong. 47 (2009) (prepared statement of John C. Coates IV, John F. Cogan, Jr. Professor of Law and Economics, Harvard Law School) ("While the two legal contexts are not identical, there is no evidence in the existing literature to suggest that the 
that the internal costs of implementing say-on-pay will likely force most corporations into a narrow range of compensation plans and limit the number of corporate actors capable of influencing the compensation decision, ${ }^{81}$ or even passing control to outside advisory firms. ${ }^{82}$ Not only could that have exactly the opposite effect of that intended-allowing capture of the compensation decision-but it also eliminates the ability of boards to experiment in an effort to find more efficient forms of compensation. ${ }^{83}$ Even more troubling, it would hinder corporate boards in their central role, finding an efficient mix of accountability and discretion. ${ }^{84}$

At best, then, say-on-pay purports to solve a problem that may not exist, has a shaky empirical foundation, and risks doing serious damage to our corporate system. The one thing it has going for it is that powerful interest groups have long desired it, ${ }^{85}$ and the economic crisis provided an atmosphere in which Congress was willing to buy what they were selling.

differences would turn what would be a good idea in the U.K. into a bad one in the U.S.").

81. See Jeffrey N. Gordon, "Say on Pay": Cautionary Notes on the U.K. Experience and the Case for Shareholder Opt-in, 46 HARV. J. LEGIS. 323, 325-35 (2009) ("[W]e should avoid another rush to widespread adoption of a particular normative conception of executive compensation.").

82. See Bainbridge, supra note 5, at 1810-11 ("[B]ecause many institutional investors rely on proxy advisory firms, a very small number of gatekeepers will wield undue influence over compensation. This likely outcome seriously undercuts the case for say-on-pay.").

83. Admittedly, in a market where all firms were similarly handicapped, it could be the case that no firm would be disproportionately disadvantaged in the market for corporate executives or many of the other markets in which corporations compete, see Butler, supra note 49, at 110-20, but that would also dramatically increase the importance of the concerns raised by Berle and Means since corporate boards would have less discretion in finding ways to control self-dealing by executives. See generally Adolf A. Berle \& Gardiner C. MEAns, The Modern Corporation AND PRIVATE ProperTy (1932).

84. See Bainbridge, supra note 5, at 1815 ("Establishing the proper mix of discretion and accountability thus emerges as the central corporate governance question. Unfortunately, it is also a question no one in Congress appears to have pondered in connection with say-on-pay; instead, only accountability concerns seem to have mattered.").

85. See id. ("Dodd-Frank's executive compensation provisions are yet another example of quack corporate governance. They were strongly supported by institutional investors. In particular, say-on-pay is a long-standing institutional investor agenda item."). 


\section{Independent Compensation Committees}

Dodd-Frank directs self-regulatory organizations (SROs) to adopt standards that require each member of a corporation's compensation committee to be independent, ${ }^{86}$ even though the empirical evidence is weighted against the conclusion that independence of compensation committees correlates with improved compensation practices or firm performance. ${ }^{87}$ Recall that, as reviewed by Romano, the weight of the evidence was also against the Sarbanes-Oxley requirement that audit committees be independent. 88 "Independence," it would seem, is a common ingredient in quack corporate governance, appealing to policymakers who favor the remedy, but without empirical support.

\section{Expanded Clawback Provisions}

Dodd-Frank also requires SROs to require disclosure of claw-back policies, the means by which corporations recover any incentive-based compensation to executives if there is a violation of reporting requirements. ${ }^{89}$ Any corporation that does not do so must be delisted. ${ }^{90}$ In addition, Dodd-Frank requires that the policy specifically provide for recovering the difference between what the executive received and what would have been received if the financial reports had been correct. ${ }^{91}$ As adopted, the provisions are both over- and under-inclusive, potentially punishing many executives that have no role in financial reporting while failing to guarantee liability for those who actually perpetrate falsehoods. ${ }^{92}$

86. Dodd-Frank, Pub. L. No. 111-203, § 952(a), 124 Stat. 1376 (2010).

87. See Bainbridge, supra note 5, at 1805 (referring to characteristics of quack corporate governance); see also Iman Anabtawi, Explaining Pay Without Performance: The Tournament Alternative, 54 EMORY L.J. 1557, 1582-83 (2005) (collecting and reviewing studies).

88. See supra Part II.A.1 (discussing the independent audit committee requirement).

89. Dodd-Frank § 954.

90. Id.

91. Id.

92. See Bainbridge, supra note 5, at 1806 ("[A]s a deterrent to financial 
The provisions are therefore highly unlikely to be successful in curbing bad executive behavior, but the provisions will also serve to limit performance-based compensation, opening the door to greater misalignment between the interests of management and of shareholders. ${ }^{93}$

\section{Shareholder Access Rule}

Released as proposed Rule 14a-11 on August 25, 2010, DoddFrank provided express authority for the SEC to proceed with its proxy access rules. ${ }^{94}$ The rule requires corporations to include on corporate proxy materials the nominees of shareholders holding at least three percent of outstanding shares continuously for at least three years. ${ }^{95}$ The rulemaking process was obviously far advanced when Dodd-Frank was passed, so this provision was unnecessary. ${ }^{96}$ As such, this provision may have been largely harmless quackery, but the rule itself has the potential to cause increased board conflict, making it harder for corporate boards to function efficiently. ${ }^{97}$ Moreover, this was heavily lobbied for by a powerful special interest-institutional investors, who have their

reporting fraud and error, it is overinclusive.... On the other hand,... the policy . . . applies only to a 'very limited number of employees."').

93. See id. at 1807 ("In response to SOX's much narrower clawback provision, "companies increased non-forfeitable, fixed-salary compensation and decreased incentive compensation, thereby providing insurance to managers for increased risk."”).

94. See id. at 1802 (noting the status of proxy access rules under DoddFrank).

95. See Facilitating Shareholder Director Nominations, 75 Fed. Reg. 56,668 (Sept. 16, 2010) ("The new rules will require, under certain circumstances, a company's proxy materials to provide shareholders with information about, and the ability to vote for, a shareholder's, or a group of shareholders', nominees for director.").

96. See Bainbridge, supra note 5, at 1802 ("An SEC rulemaking proceeding on proxy access was well advanced long before Dodd-Frank was adopted, so a shove from Congress was superfluous.").

97. See id. at 1803 ("The likely effects of proxy access therefore will not be better governance. It is more likely to be an increase in interpersonal conflict (as opposed to the more useful cognitive conflict)."). 
own interests that may not coincide with the interests of shareholders, generally. ${ }^{98}$

\section{Disclosure Requirements}

Dodd-Frank requires disclosure, in annual proxy statements, of the relationship between the financial performance of the firm and the compensation received by executives, as well as the annual total compensation of the CEO, the median annual total compensation of all the corporation's employees (excluding the CEO), and a ratio of CEO compensation to the median. ${ }^{99}$ Also required is the public disclosure of whether a single individual holds the positions of $\mathrm{CEO}$ and chairman and the reason for choosing a particular structure. ${ }^{100}$ Bainbridge refers to these provisions as "therapeutic disclosures," intended to push corporations towards a single model of compensation and board structure. ${ }^{101}$

Initially, this might seem contradictory to Romano's discussion of quackery, in that Romano offers disclosures as a preferred alternative to the type of regulations mandated by

98. See id. at 1804 (quoting Kathleen L. Casey, Comm'r, U.S. Sec. \& Exch. Comm'n, Statement at Open Meeting to Adopt Amendments Regarding Facilitating Shareholder Director Nominations (Aug. 25, 2010)). Professor Alicia Davis has argued that institutional investors prefer the type of strong internal controls mandated by Sarbanes-Oxley and Dodd-Frank because they believe them to be value enhancing. Alicia J. Davis, The Institutional Appetite for Quack Corporate Governance, 2105 CoLum. Bus. L. REV. 1, 71. However, that still leaves open the question of what those institutional investors value, and it could be something other than wealth. Professor Davis finds it unlikely that all categories of institutional investors-pension funds, mutual funds, insurance companies, banks- "are motivated by political considerations over return maximization," $i d$. at 66 , which is almost certainly true, but it also misses the point. Some of those institutional investors could prefer strong internal controls for political considerations because that is what they value, but others could still have preferences that diverge from those of the average shareholder who wishes to maximize returns and know that they will be better able to assert their influence after strong internal controls are put in place.

99. Dodd-Frank, Pub. L. No. 111-203, § 953, 124 Stat. 1376 (2010).

100. Id. $\S 972$.

101. See Bainbridge, supra note 5, at 1797 ("Therapeutic disclosures are not intended to inform investors. Instead, they are intended to affect substantive corporate behavior."). 
Sarbanes-Oxley, ${ }^{102}$ but the distinction is understandable in context. Romano advocates providing shareholders basic information regarding audit procedures, which will allow shareholders and financial markets to determine the efficient solutions. ${ }^{103}$ Conversely, the Dodd-Frank disclosures on compensation require collection and dissemination of information not collected in the normal course of business, ${ }^{104}$ and that is unrelated to the operation of a corporate enterprise. ${ }^{105}$ DoddFrank's board structure disclosures are also not designed to inform shareholders, but rather to shame corporations into separating the two positions. ${ }^{106}$ There is also no evidence that the disclosures will have a positive impact on the corporations that conform their structure to public shaming. ${ }^{107}$

102. See Romano, Making of Quack Corporate Governance, supra note 5, at 1527-28 ("[The provisions] could have been formulated as disclosure mandates. Had that been done, those provisions would have fallen within the conventional regulatory apparatus. Instead, they were imposed as substantive mandates, a different and more costly regulatory approach.").

103. See id. at 1542 (relating how market pressures punished firms that maintained "opaque financial statements").

104. See Bainbridge, supra note 5, at 1797 ("This information would undoubtedly be extremely time-consuming to collect and analyze, making it virtually impossible for a company with thousands of employees to comply with this section of the Act.").

105. See id. at 1798 ("The law taps into public anger at the increasing disparity between the faltering incomes of middle America and the largely recession-proof multimillion-dollar remuneration of the typical corporate chief." (quoting Jean Eaglesham \& Francesco Gurerrera, US Pay Law Branded 'Logistical Nightmare,' FIN. TIMES (Aug. 31, 2010), https://www.ft.com/content/977211ac-b461-11df-8208-00144feabdc0 (last visited Nov. 2, 2017) (on file with the Washington and Lee Law Review))).

106. See id. (referring to policy entrepreneurs who "hope that the provision will shame companies into separating" the CEO and chairman positions).

107. See id. (arguing that the claim that separating the positions will have positive impacts is "without compelling support in the empirical literature"); see also Protecting Shareholders and Enhancing Public Confidence by Improving Corporate Governance: Hearing Before the Subcomm. on Sec., Ins., \& Inv. of the S. Comm. on Banking, Hous., \& Urban Affairs, 111th Cong. 47-48 (2009) (statement of John C. Coates IV, Professor of Law \& Economics, Harvard Law School) ("The only clear lesson from these studies [comparing split and unified Chair/CEO positions] is that there has been no long-term trend or convergence on a split chair/CEO structure."). Bainbridge points out that a unified structure can limit board oversight of a CEO's performance, but only because independent board members have ceded too much power to the chairman; reclaiming that 
In addition to the specific characteristics of Dodd-Frank's disclosure rules that show them to be quackery-enacted by desperate politicians at the behest of special interests with no evidence of likely efficacy-any form of therapeutic disclosure should be looked at skeptically. ${ }^{108}$ Traditional disclosure is useful because it allows markets to operate more effectively. ${ }^{109}$ It does this by giving market actors the information that helps set the price of corporate securities. ${ }^{110}$ Therapeutic disclosure mandates require collection and disclosure of information that is not intended to inform market actors but, instead, coerce corporations into making specific changes that were not chosen in a well-functioning market. ${ }^{111}$ Because these changes could not be achieved in the market, their success through regulation will be the result of pressure brought by institutional investors who want them for purposes other than the welfare of the corporation. ${ }^{112}$ These special interests can get what they want only if Congress buys their quackery.

\section{The Salesmen}

Dodd-Frank's solutions to perceived corporate governance problems seem quite poorly designed, even if the perceived problems are real. ${ }^{113}$ The empirical evidence does not support any

power solves the problem without effectively mandating a split structure. See Bainbridge, supra note 5, at 1800 (advocating the adoption of such steps as by-laws allowing board members to call special meetings and require periodic meetings outside the presence of managers).

108. See Bainbridge, supra note 5, at 1797 (arguing that therapeutic disclosures are not intended to inform investors, but to affect corporate behavior).

109. See Butler, supra note 49, at 106 (explaining how information reaching investors through voluntary and mandatory disclosures, news stories, and analyst reports affects market efficiencies).

110. See id. (describing the Efficient Capital Markets Hypothesis).

111. See Bainbridge, supra note 5, at 1797-1801 (discussing how the Pay Disclosures and Board Structure Disclosure of Dodd-Frank were intended to affect substantive corporate behavior).

112. See id. at 1801 (citing the role of institutional investors, who possess more clout at the federal level than state level, as satisfying one of the criteria for quack corporate governance).

113. As with Romano, Bainbridge argues that, whatever flaws might exist in 
of the proposals but Congress bought the sales pitch that these were wonderful remedies. ${ }^{114}$ Who was selling these particular formulas of snake oil? Bainbridge identifies institutional investors as the relevant policy entrepreneurs, especially unions and state and local pension funds. ${ }^{115}$ Particularly with say-on-pay and proxy access, but also with other provisions, institutional investors had long desired this outcome, ${ }^{116}$ and they will certainly be the most likely to use these new powers to generate additional returns for themselves, possibly at the expense of the corporation and other shareholders. ${ }^{117}$ In other words, a remedy was purchased for a

state corporate governance laws, those laws did not contribute to the collapse that led to Dodd-Frank. Id. at 1815; see also Brian R. Cheffins, Did Corporate Governance "Fail" During the 2008 Stock Market Meltdown? The Case of the S\&P 500,65 BUs. LAW. 1, 2 (2009) ("A striking aspect of the stock market meltdown of 2008 is that it occurred despite the strengthening of U.S. corporate governance over the past few decades and a reorientation toward the promotion of shareholder value.").

114. See supra note 87 and accompanying text (discussing that empirical evidence weighs against independence of compensation committees improving compensation practices or firm performance); supra notes 76-79 and accompanying text (highlighting empirical evidence against the efficacy of say-on-pay provisions).

115. See Bainbridge, supra note 5, at 1816 (identifying these groups as "able to hijack the legislative process to advance a long-standing political agenda").

116. Id. The Council of Institutional Investors (CII) provided the Senate Committee with written testimony in support of the say-on-pay provision. S. REP. No. 111-176, at 134 (2010). Additionally, The Chief Investment Officer of the California Public Employees' Retirement System, Joseph Dear, wrote in testimony for the Senate Banking Committee that "[b]oards of directors should be encouraged to separate the role of chair and CEO, or explain why they have adopted another method to assure independent leadership of the board." Id. at 147. CII also wrote to Senator Dodd to support reforms requiring credit rating agencies to use methodologies approved by boards of directors and disclose qualitative and quantitative information to enable investors to better understand credit ratings. $I d$. at 119-20.

117. As one example, the union representing Safeway employees was a Safeway shareholder and used proxy access in an attempt to oust board members who had stood up to union leadership during collective bargaining negotiations. Bainbridge, supra note 5, at 1817. SEC Commissioner Kathleen Casey apparently agrees with that assessment, pointing out in her dissent from the new rule, that:

The paradigm of a power struggle between directors and shareholders is one that activist, largely institutional, investors assiduously promote... . Yet, these shareholders do not necessarily represent the interests of all shareholders, and the Commission betrays its mission when it treats these investors as a proxy for all shareholders. 
malady that might not exist, the remedy would not likely work, anyway, and only the purveyor of the quack remedy is enriched.

\section{The Quackery Hypothesis}

As formulated by Romano and refined by Bainbridge, quackery in corporate governance regulation usually arises in the wake of a significant negative market event, as that event generates both hostility towards corporations in public sentiment and public pressure on Congress to do something. ${ }^{118}$ The regulation comes in a form that was crafted before the crisis in a way that it can be "readily adapted into legislative form" by an interest group that has its own reasons for desiring the regulation. ${ }^{119}$ This implies that the solutions are, to some extent, in search of a problem that will serve as a suitable vehicle for the reforms, rather than solutions designed to fix an identified problem. Furthermore, the remedy has no strong empirical support-either the empirical evidence argues strongly against enactment of the policy or, at best, the evidence is mixed. ${ }^{120}$

Kathleen L. Casey, Comm'r, U.S. Sec. \& Exch. Comm'n, Statement at Open Meeting to Adopt Amendments Regarding Facilitating Shareholder Director Nominations (Aug. 25, 2010), (transcript available at https://www.sec.gov/news/speech/2010/spch082510klc.htm).

118. Bainbridge elaborates on the role of bubbles in generating the lax enforcement during the boom-which increases risk dramatically-and exacerbating the overreaction when the bubble bursts. See generally Bainbridge, supra note 5, at 1785-86. The rising values of nearly all portfolios can lull regulators into a false sense of security and lower the level of oversight given by regulators. Id. Reacting to the lower level of scrutiny, many financial entities will increase their risk levels beyond what would otherwise be appropriate, and many will engage in outright fraud. Id. When the bubble inevitably bursts, that increased risky behavior and fraud provides ample justification for Romano's policy entrepreneurs (Bainbridge's “anticorporate populists"), id. at 1784, to push for additional regulation. Id. at 1786; see also Romano, Making of Quack Corporate Governance, supra note 5, at 1591-94 (tracing this recurring phenomenon back before the New Deal to the Future Trading Act of 1921); Ribstein, supra note 45, at 79 (referring to this cycle as the "boom-bubble-bustregulate cycle of financial market regulation").

119. Bainbridge, supra note 5, at 1786.

120. See supra note 87 and accompanying text (discussing the empirical evidence results for various provisions of Dodd-Frank). 
The historical snake-oil salesman operated in very similar fashion, packaging a "remedy" that had no foundation in medical science, then selling it as a cure for anything that might ail the potential customer. ${ }^{121}$ Some victims might be especially gullible, but the primary success of the early American quack would have arisen out of moments of crisis, when the "patient" was desperate for a cure. ${ }^{122}$ Modern day medical quacks might be more technologically advanced,123 but the conditions for a successful quackery scam are the same: crisis in the life of the "patient," a prepackaged remedy - who has time to wait for a tailored remedy when there is money to be made-and money in the pocket of the quack. ${ }^{124}$ Unfortunately, the scenario also plays out in our regulatory system.

One way to appreciate the suitability of the quackery analysis is to view it in light of the evolution of medical regulation, except in reverse. One commentator describes the late nineteenth and early twentieth centuries as detrimental to public health-and particularly vulnerable populations-because anyone could market a medical remedy and the Food and Drug Administration (FDA) had to show that the remedy was not safe before it could be removed. ${ }^{125}$ The difficult task of proving a negative meant that the time between introduction of a new medical remedy and any adverse action by the FDA would be substantial and the cost "in terms of human suffering" during that time span could be high. ${ }^{126}$

121. See Van Tassel, supra note 27, at 219 (using Swaim's Panacea, a quack remedy claimed to cure cancer, scrofula, rheumatism, gout, hepatitis, and syphilis as an example).

122. See id. at 216-17 ("[T] he degree of gullibility was proportional to the level of desperation of the individual for a cure.").

123. See id. at 213-15 (discussing the weight-loss supplement industry). The California Bureau of Food and Drug Inspections has confiscated any number of more modern devices that had been represented as having a valid remedial or diagnostic use: a converted juke box; a common steel ball; an overhauled five-tube radio: a floodlight behind a piece of red glass; and the Calozone Ozone Generator, a device that generated high levels of potentially deadly ozone. Quackery in California, supra note 26, at 265-66.

124. Van Tassel, supra note 27, at 219.

125. See id. at 216 (lamenting that during this lag time "predatory commercial interests" could profit from the scientific uncertainty).

126. Id. at 217. 
Moreover, the only limit on the success of quacks was "the gullibility of their targets," which was usually "proportional to the level of desperation of the individual for a cure." 127

Eventually, the burden shifted, and now the producer of a medical device or other remedy must prove its safety and effectiveness before it will be allowed to market that product. ${ }^{128}$ This historical shift is seen as a positive development ${ }^{129}$ yet, if the quackery hypothesis is correct, the trend in regulation is in the opposite direction. Today, regulatory "solutions" can be enacted without any evidence of their safety or effectiveness and anyone who insists on empirical support bears the burden of proving that the regulations are harmful. ${ }^{130}$ That burden is difficult and the time spent amassing the empirical evidence represents irreparable harm to capital markets, the economy as a whole, and individual market participants who bear the costs of regulatory quackery.

In this way, regulatory quackery is worse than medical quackery; a victim of medical quackery must be convinced to pay the costs and those costs fall almost exclusively on the victim. ${ }^{131}$

127. Id. at $216-17$.

128. See id. at 217 (noting that it took a series of "highly publicized health crises to create the political will" to require manufacturers to obtain preapproval for new drugs).

129. There are some who argue that our current regulatory scheme for medical technology leads to greater death and morbidity by increasing the cost of drug development and delaying the availability of life-saving drugs. See Ariel Katz, Pharmaceutical Lemons: Innovation and Regulation in the Drug Industry, 14 Mich. Telecomm. \& Tech. L. Rev. 1, 7-12 (2007) (describing the most common objections to the current regulatory regime).

130. See, e.g., Bainbridge, supra note 5, at 1796 (pointing out the way SEC regulators dismissed empirical evidence that did not support the regulation while treating supportive studies as "if these studies were on point and above critique when in fact they are not" (quoting Troy A. Paredes, Comm'r, U.S. Sec. \& Exch. Comm'n, Statement at Open Meeting to Adopt the Final Rule Regarding Facilitating Shareholder Director Nominations ("Proxy Access") (Aug. 25, 2010) (transcript available at http://www.sec.gov/news/speech/2010/spch082510tap. htm))).

131. There is a possibility for some spillover costs associated with an individual failing to receive real medical care in a timely fashion because a quack remedy has distracted the individual. For example, a condition might unnecessarily worsen, requiring a greater amount of medical care than if caught earlier. That increase in the demand for health care services will raise prices and force others obtaining care at the same time to pay more, either in money or time costs. See David E. Newman-Toker et al., How Much Diagnostic Safety Can We 
With regulatory quackery, however, hundreds of millions can be victimized after convincing only a few hundred individuals-a majority of both houses of Congress and the President. ${ }^{132}$ The cost of regulatory quackery, therefore, is certain to be orders of magnitude greater than the cost of medical quackery. Moreover, while any decision to purchase a quack remedy-medical or regulatory-becomes more likely the greater the crisis, ${ }^{133}$ a victim of medical quackery is buying in order to maximize individual net benefits, but the purchaser of regulatory quackery is buying something else entirely-likely another term in office. Eliminating medical quackery, therefore, is a question of providing the correct information so that individuals will realize that the benefit is zero. ${ }^{134}$ Regulatory quackery, on the other hand, cannot be so easily corrected. Although political actors may know that the remedy is useless or harmful, they might buy the remedy anyway, because those costs can be hidden in the overall complexity of government regulation. ${ }^{135}$

Of course, the quackery hypothesis is not without its critics. One obvious avenue of disagreement is that Romano and Bainbridge are simply wrong about the ability of Sarbanes-Oxley and Dodd-Frank to achieve any positive ends. ${ }^{136}$ This critique may

Afford, and How Should We Decide, 22 BMJ QuALITY \& SAFETY (SUPPLEMENTAL ISSUE 2) 11, 11 (2013) (suggesting indirect costs arise from medical misdiagnosis in the form of defensive medicine, increased liability premiums, and other "downstream effects" to over $\$ 45$ billion).

132. If quack regulations were arguably within existing statutory authority, the number of people who would need to be convinced to buy the sham remedy could be dramatically lower. Because the purchase decision would reside within the regulatory agency, it could, theoretically, be made by a handful of individuals.

133. See Van Tassel, supra note 27, at 216-17 ("The more dire the condition, the more vulnerable an individual was to the 'flim flam' of the greedy snake oil salesman.").

134. See id. at 220-21 (explaining the early efforts of the FDA to weed out quack medicine).

135. Political actors may use a time of crisis to increase (comparing the Dodd-Frank response to Robert Higgs "ratchet" theory where the government wades into a sphere during a crisis, becomes entrenched, and then does not retreat because interest groups have an incentive to preserve the status quo).

136. See, e.g., Robert A. Prentice \& David B. Spence, Sarbanes-Oxley as Quack Corporate Governance: How Wise is the Received Wisdom, 95 GEO. L.J. 1843, 1845 (2007) (arguing that Romano and Bainbridge, among others, err in concluding that "statutory enactments that do not accord with the majority view 
be correct, but it is beside the point of the broader quackery critique, given that some of those same critics concede the procedural point, that Congress does not give careful consideration to the empirical support for policy proposals. ${ }^{137}$ Whether or not there is large-scale damage to the economy from regulatory

of an array of disparate studies reaching a broad range of conclusions are automatically major gaffes" and that later analyses of the data "actually supports several of the provisions that Romano and others critique"). Prentice and Spence also argue that times of crisis are necessary to overcome the stranglehold that business interests have over the regulatory process. Id. at 1845-46. However, their argument fails because they rely too heavily on a misreading of the regulatory capture literature. It is true that business interests will often have incentives to combine to manipulate the regulatory process, $i d$. at 1847 , but they are hardly the only group that possesses those incentives. Mancur Olson, who Prentice and Spence cite approvingly, is very clear that it is smaller groups with closely aligned interests that have these incentives. MANCUR OLSON, THE LOGIC of Collective ACtion: Public Goods AND the Theory of Groups 22-43 (1975). However, they are simply wrong to assert that Olson believes that "businesses" are more likely to engage in this behavior. Prentice \& Spence, supra, at 1847. Instead, Olson makes a distinction between "inclusive" and "exclusive" groups, and argues that exclusive groups-market groups-are more likely to attempt capture to erect barriers to entry. OLSON, supra, at 37 . While an easy mistake to make, it is incorrect to assume that "market" equals "business" in a strict sense, for Olson's definition of exclusive groups indicates that many non-business groups would be included. See id. at 37 n.56 (using social clubs as an example). The defining characteristic is whether the group wishes for fewer, rather than more, participants. Id. at 37. Unions, institutional investors, and all of the policy entrepreneurs identified by Romano and Bainbridge clearly fall within the "exclusive" category.

137. See, e.g., Prentice \& Spence, supra note 136, at 1845 ("[W]e concede that Congress did not examine the empirical academic literature as thoroughly as it might have (or perhaps at all)."). Other criticisms are even more beside the point, such as the one that posits essentially a temper tantrum by Romano and Bainbridge because their preferred model of corporate law-the contractarian model-was superseded by absolutes in federal law. See generally J. Robert Brown, Jr., Criticizing the Critics: Sarbanes-Oxley and Quack Corporate Governance, 90 MARQ. L. REV. 309, 310, 316-18 (2006). Brown describes the "likely" positive-though "modest"-changes that he believes will result from Sarbanes-Oxley, id. at 319, but his belief could also be no different from the average purchaser of snake oil. More fundamental is his rejection of the contractarian model of corporate law, largely because he believes the decline in takeovers destroys the practical viability of the check on self-dealing by corporate managers. Id. at 312-13. This caricature of the model is largely a straw man, because contractarians believe corporations compete in a wide range of markets, not just the market for corporate control. See Butler, supra note 49, at 110-17 (discussing the involvement of corporations in the stock market, product market, and capital markets, among others). 
quackery is a guessing game under those circumstances. The Congress that buys such a remedy may hope for the best, but so do all who purchase quack medical remedies. ${ }^{138}$ Moreover, it is even possible for quack remedies to have random positive effects, possibly as placebo effects. ${ }^{139}$

Our nation's history regarding medical quackery is in stark contrast with the ongoing trends in regulatory quackery. Instead of beginning with the presumption that regulatory solutions are safe and effective-something we have abandoned in the medical field ${ }^{140}$ — we should demand evidence that those solutions are likely to work. Such a demand is not likely to be popular during a crisis but, as our history with medical quackery should teach us, crises are when evidence and caution are most important. ${ }^{141}$

Yet, as important as the quackery hypothesis is to understanding that there is something wrong with the way we approach regulation in our modern world, it is still missing something. Although Bainbridge more clearly illuminates the role of interest groups in adopting quackery, ${ }^{142}$ he also stops short of expressly asking whether their interest is merely a mistaken understanding of how markets work-so that the costs imposed are the result of negligence-or whether they are designed to

138. See Sheldon Richman, Dodd-Frank Only Makes Things Worse, Am. Inst. FOR ECON. RES. (Apr. 20, 2017), https://www.aier.org/research/dodd-frank-onlymakes-things-worse (last visited Nov. 20, 2017) (explaining Dodd-Frank as the result of common government intervention: "pile new regulations atop old, and hope for the best") (on file with the Washington and Lee Law Review); Quackery in California, supra note 26, at 267 (describing the victims of quackery as "the hopeless" and the "miracle seekers").

139. For a medical description of placebos, see Thomas, supra note 27, at 31315 (relating anecdotes of terminal patients whose lifespans were incredibly extended because they believed in the curative effects of placebos).

140. See Van Tassel, supra note 27, at 216 (discussing how the FDA's premarket enforcement process places the cost and burden on product manufacturers to show that their products are safe and effective).

141. See id. at 217 (suggesting that where conditions were most dire, the more vulnerable people were to deception and the greater the resulting harm when the sham medicine did not work).

142. See Bainbridge, supra note 5, at 1816 ("Dodd-Frank's corporate governance provisions were included in the legislation because key policy entrepreneurs were able to hijack the legislative process to advance a long-standing political agenda.”). 
achieve specific goals other than those expressed by policymakers. ${ }^{143}$ For example, he identifies that proxy access has been the "pet project" of large, institutional investors for some time,${ }^{144}$ but does not elaborate as to the specific benefits that they hope to gain with the change. ${ }^{145}$ Even when discussing say-on-pay, which he identifies as being supported by unions and consumer protection groups and opposed by business groups, ${ }^{146}$ he does not identify the competing interests that draw such attention.

To be clear, both Romano and Bainbridge appear to understand and appreciate that special interests seek individual benefits from general policy prescriptions. ${ }^{147}$ Yet, their analysis of quackery is lacking the formal distinction between quackery motivated by negligence and that explicitly motivated by parochial interests. More importantly, their analysis largely avoids consideration of the potential for non-shareholder third-parties to intervene-perhaps surreptitiously-in the legislative process in order to achieve goals that have nothing to do with the relationship between shareholders and management. The next section provides the theoretical tool necessary to fill that gap. In colorful fashion, it adds bootleggers to our discussion of quackery.

\section{Bootleggers and Baptists}

143. See generally id. (stopping short of asking whether this is a result of negligence).

144. Id. at 1804.

145. See generally id. (avoiding discussion of any specific benefits).

146. See id. at 1808 (stating no more than that the issue "was highly contentious" and listing the groups on either side of the issue).

147. See Roberta Romano, Less is More: Making Shareholder Activism a Valued Mechanism of Corporate Governance, 18 YALE J. ON REG. 174, 231-32 (2001)

It is quite probable that private benefits accrue to some investors from sponsoring at least some shareholder proposals.... Examples of potential benefits . . . are progress on labor rights desired by union fund managers and enhanced political reputations for public pension fund managers, as well as advancements in personal employment.

See also Bainbridge, supra note 5, at 1816 ("It seems reasonable to assume that these same activist investors will be the shareholders most likely to make use of their new powers."). 
Regulation-financial or otherwise-is often thought of as a way of correcting market failures, ${ }^{148}$ and laws and regulations like Sarbanes-Oxley and Dodd-Frank are often promoted based on that justification, ${ }^{149}$ yet it can also be an opportunity to pursue private gain outside of a market context. It might seem obvious that those who bear the costs of regulation would lobby for its repeal; instead, they often argue in favor of regulation. ${ }^{150}$ This

148. See Bruce Yandle \& Stuart Buck, Bootleggers, Baptists, and the Global Warming Battle, 26 HARV. ENVTL L. REV. 177, 185-86 (2002) (describing the public interest theory of regulation); Brown, supra note 137, at 311-18 (arguing that the market for corporate control has ceased to function, removing essential market mechanisms for policing director behavior). The term "market failure" has a reasonably precise definition: some circumstance that interferes with market mechanisms and precludes prices from adjusting to achieve efficient outcomes. See, e.g., Henry N. Butler, Christopher R. Drahozal \& JoAnna Shepherd, ECONOMIC ANALYSIS FOR LAWYERS 125-26 (3d ed. 2014) (recognizing that market failures often become justifications for governmental intrusion). The term is used colloquially in far less precise fashion, often referring to any market outcome that does not match the speaker's normative view of what the world should look like. As it turns out, those suboptimal outcomes can be the result of prior government action, making further government intervention unwise. See, e.g., Ronald Coase, The Problem of Social Cost, 3 J.L. \& ECON. 1, 28 (1960)

The kind of situation which economists are prone to consider as requiring corrective Government action is, in fact, often the result of Government action. Such action is not necessarily unwise. But there is a real danger that extensive Government intervention in the economic system may lead to the protection of those responsible for harmful effects being carried too far.

See also Jeremy Kidd, Kindergarten Coase, 17 Green BAG 2D 141, 149 (2014) (making Coase's theories more accessible and understandable); Jeremy Kidd \& Joseph R. Padgett, Trucker Shortage as Government Failure, 1 LoY. U. CHI. J. REG. COMPLIANCE 7 (2016) (arguing that the U.S. trucker shortage is the result of unhelpful Department of Transportation safety regulations).

149. See BUTLER ET AL., supra note 148, at 125-26 (discussing market failure as a normative ground for government intervention). Other theories of regulation criticize this approach. In the capture theory, regulatory bodies become captive to the regulated industries, which use regulation to cartelize the industry and reduce competition. Yandle \& Buck, supra note 148, at 186 . In the economic theory of regulation, formulated by George Stigler, regulation is merely another tool by which producers maximize profits. See id. ("[A]s a rule, regulation is acquired by the industry and is designed and operated for its benefit." (quoting George Stigler, The Theory of Economic Regulation, 2 BELL J. ECON. \& MGMT. ScI. 3, 3 (1971))).

150. See Yandle, Bootleggers and Baptists, supra note 6, at 13 (positing that industry representatives may be okay with regulations, so long as they can still minimize their own costs). 
phenomenon is not new, with London weavers' demanding and receiving specific regulatory mention in the Magna Carta in the thirteenth century. ${ }^{151}$ In modern times, examples include biotech companies lobbying for government standards on their gene-spliced crops, ${ }^{152}$ cigarette companies lobbying for regulation of their own e-cigarette lines, ${ }^{153}$ and industry lobbying for environmental regulations. ${ }^{154}$ The most extreme example of this would be sellers of illegal products lobbying to maintain their illegal status, such as bootleggers during Prohibition. ${ }^{155}$

The rationale for this behavior is simple: regulations inhibit competition, particularly from new market entrants that are deterred by the burden of the new regulations. ${ }^{156}$ Even more attractive is regulation that inhibits competition in a way that imposes costs on everyone else, particularly competitors but also potentially consumers. ${ }^{157}$ For example, if you own large swaths of private forest just perfect for logging, you might lobby for restrictions on logging in public forests in order to increase the

151. See id. at 12 ("[T]he Magna Carta require[ed] all cloth woven in the realm to be of uniform dimensions-conforming to the London standard.").

152. Henry I. Miller \& Gregory Conko, Bootleggers and Biotechs, REGULATION, Summer 2003, at 12 .

153. See Jonathan H. Adler et al., Baptists, Bootleggers \& Electronic Cigarettes, 33 YALE J. ON REG. 313, 348 (2016) (hinting that encouraging regulations is a way of preventing new brands or products from entering the market).

154. See Todd Zywicki, Environmental Externalities and Political Externalities: The Political Economy of Environmental Regulation and Reform, 73 TUL. L. REV. 845, 856-74 (1999) (explaining that regulation can benefit industry by increasing demand or restricting entry of competitors); see also A.H. Barnett \& Timothy D. Terrell, Economic Observations on Citizen-Suit Provisions of Environmental Legislation, 12 DUKE ENVTL. L. \& POL'Y 1, 25 (2001) (quoting William Y. Brown, an officer of WMX, the nation's largest waste management company, as supporting stricter environmental regulation because "[s]tricter legislation is environmentally good and it also helps our business").

155. See Brenner M. Fissell, Abstract Risk and the Politics of the Criminal Law, 51 AM. CRIM. L. REV. 657, 674 (2014) ("[C]ontinued prohibition was supported even by those who took a morally opposite stance (the bootleggers), all because they reaped the monetary rewards of the illegality.").

156. Adler et al., supra note 153, at 348 .

157. See Fissell, supra 155, at 674 (explaining the economic self-interest in industry advocating environmental regulations as "raising rivals' relative cost"). 
value of your land and your trees. ${ }^{158}$ The result of these efforts is typically higher prices and increased profits. ${ }^{159}$

This rent-seeking ${ }^{160}$ is predicted by public choice economists, but it often leads to the formation of coalitions that defy conventional wisdom. For example, when President Barack Obama announced new fuel economy standards on May 16, 2009, those standards were cheered by automobile executives, union leaders, and environmental groups. ${ }^{161}$ Some observers, such as Obama Press Secretary Robert Gibbs, offered positive spin, that the diverse coalition supporting the changes was something to be desired, ${ }^{162}$ but diverse and unusual coalitions can also be a sign that there is more going on than is initially obvious. ${ }^{163}$ Diverse coalitions may be a sign that the inevitable unintended consequences ${ }^{164}$ might not have been unintended, after all. When things go awry and the policy's flaws appear, they may just be revealing the reason the bootleggers got involved in the first place.

158. See Bruce Yandle, Bootleggers and Baptists in Retrospect, REGULATION, Fall 1999, at 5, 6 [hereinafter Yandle, Bootleggers in Retrospect] (describing how Weyerhauser Corporation, a timber company, encouraged prohibiting logging on federal lands, ostensibly to protect owl habitats, which resulted in unusually high returns to its own privately held and adjacent timberlands).

159. Id.

160. Rent-seeking is the process by which individuals seek to obtain personal benefits by manipulating public decision-makers, whether regulators or legislators. The phrase "rent-seeking" was coined by Anne O. Kreuger in The Political Economy of the Rent-Seeking Society, 64 Am. Econ. REV. 291 (1974), based on Gordon Tullock's earlier work on regulatory agencies, The Welfare Costs of Tariffs, Monopolies and Theft, 7 W. ECON. J. 224 (1967).

161. Bruce Yandle, America's New Fuel Economy Cartel, Regulation, Fall 2009, at 6-7 (2009).

162. See id. at 6 ("You will see people that normally are at odds with each other in agreement with each other.").

163. See id. at 6-9 (applying the "Bootlegger and Baptist" theory to explain the convergence of interests behind the new fuel standards).

164. See Paul D. Carrington, Virtual Civil Litigation: A Visit to John Bunyan's Celestial City, 98 Colum. L. REv. 1516, 1517 (1998) ("The law of unintended consequences decrees that the resolution of current problems will create or reveal new ones.”). 


\section{A. Bootlegger Theory}

Bruce Yandle first proposed the Bootleggers and Baptists theory more than thirty years ago. ${ }^{165}$ At its core, the theory explains how "durable social regulation evolves when it is demanded by ...'Baptists' [who] point to the moral high ground.... [And] Bootleggers, who expect to profit from the very regulatory restrictions desired by Baptists." 166 In other words, a regulatory change is most likely to succeed and endure when fronted by morally persuasive supporters but financed by behind-the-scenes moneyed interests. ${ }^{167}$ The theory's name was derived from the "colorful tales of states' efforts" to restrict alcohol sales on Sunday. ${ }^{168}$ Bootleggers desire one day where the competitive marketplace for alcohol is shut down, making themselves the only game in town, while the Baptists have strong moral preferences for a ban on alcohol sales on their Sabbath. ${ }^{169}$

When applied broadly, the theory helps explain some of the peculiar regulatory outcomes that emerge from various government bodies, particularly those regulations that appear to do nothing and yet somehow persist. Although the connections are often not visible to the public, coalitions form between moral crusaders and amoral profiteers and those coalitions can explain the regulatory outcomes. ${ }^{170}$ Separately, money and morality are powerful tools; combined, they gain strength beyond what can be explained by mere summation of their efforts. ${ }^{171}$ However, it should be obvious that it is not enough just to have the money and morals because the form the regulation takes must also be

165. Yandle, Bootleggers and Baptists, supra note 6, at 13.

166. Yandle, Bootleggers in Retrospect, supra note 158, at 5.

167. See Randy T. Simmons, Ryan M. Yonk, \& Diana W. Thomas, Bootleggers, Baptists, and Political Entrepreneurs: Key Players in the Rational Game and Morality Play of Regulatory Politics, 15 INDEP. REV. 367, 368 (2011) ("Bootlegger, then, is a term for those who benefit economically, and Baptist for those who provide moral cover for the regulations.").

168. Yandle, Bootleggers in Retrospect, supra note 158, at 5.

169. Yandle, Bootleggers and Baptists, supra note 6, at 13.

170. Id. at $13-14$.

171. See id. at 14 (explaining how the two tools combined can be used to benefit politicians who enact regulations). 
acceptable to the regulator. ${ }^{172}$ Understanding what each party to this dance wants most is essential to understanding how our seemingly haphazard regulatory process may actually be quite methodical.

\section{What's in it for the Baptist?173}

The Baptist is motivated by normative views about what the world should look like. ${ }^{174}$ Whether the world has too much of some pernicious evil—alcohol, in Yandle's original example—or too little of something important for human flourishing, the Baptist believes it is important for the government to take an active role in correcting the problem. ${ }^{175}$ Baptists have organizational strength, the ability to fill airwaves or protest spaces with moral arguments-verbal or written on placards-in favor of government action. ${ }^{176}$ These are powerful tools, and the Baptist can achieve some success alone. ${ }^{177}$ Achieving larger goals, however, requires

172. The use of the term "regulator" in this Article is not limited to individuals who work for those regulatory bodies that comprise the administrative state, although that is the most common usage. Instead, it can also include all those who are engaged in the lawmaking process, whether in the legislative or executive branch. See Yandle, Bootleggers in Retrospect, supra note 158, at 5-7 (explaining the role of political actors in both branches on the Kyoto Protocol). Although there are some interesting questions to be asked regarding the role of judiciary actors as regulators, see, e.g., Mario J. Rizzo, Abstract Morality for an Abstract Order: Liberalism's Difficult Problem, 23 Sup. CT. ECON. REV. 7, 26-34 (2015) (discussing the role of the judiciary in changing legal rules and the impact those changes have on markets), those questions are beyond the scope of this Article.

173. In case it is not abundantly clear, the term "Baptist" is used in a metaphorical sense only. Although the anecdotes that gave rise to Yandle's theory involved actual religionists who followed the Baptist creed, the term here refers to anyone who promotes policy based on moral grounds.

174. But see Todd J. Zywicki, Baptists? The Political Economy of Political Environmental Interest Groups 2 (Geo. Mason U.L. \& Econ. Working Paper No. 02-23, 2002), https://ssrn.com/abstract=334341 (proposing that even many purported Baptists are pursuing individual rewards, rather than the public interest).

175. Yandle, Bootleggers in Retrospect, supra note 158, at 5-6.

176. See id. at 5 (highlighting the "vital and vocal" nature of Baptists' support).

177. Id. 
more than just convincing words; government action is always costly, including the political cost of shifting the status quo. ${ }^{178}$

When the goals are particularly lofty, the Baptist will need help with those areas of the political process that do not yield to mere organizational strength. ${ }^{179}$ Monetary resources are necessary to make the most effective use of the Baptists' strength-paid media to complement any free media generated by the movement, for example. ${ }^{180}$ Bootleggers can make donations to the cause or form a front organization with an innocuous name to run complementary advertisements. ${ }^{181}$ When regulators or legislators balk at the effort required to change the law and move the status quo, the bootleggers can donate to reelection campaigns or otherwise "grease the political machinery," 182 in order to remove more tepid opposition. In economic terms, the bootlegger lowers

178. See Yandle \& Buck, supra note 148, at 188 ("Baptists lower the costs of favor-seeking for the bootleggers because politicians can pose as being motivated purely by the public interest even while they promote the interests of well-funded businesses.").

179. Id.

180. See id. at 190 (referring to the environmental context to show how media attention focuses on the environmental activists while the industrial actors work behind the scenes).

181. This description of the bootlegger places in stark contrast the fundamental-some might say irreconcilable-difference between the Baptists and the bootleggers. It can be easy to criticize the Baptist for accepting help from those whose interests are at odds with the underlying moral goals, but it is important to recall that bootleggers can direct money towards these efforts in ways that mask the true source. See Adler et al., supra note 153, at 320 ("For things to work, the Bootleggers and Baptists need only pursue similar outcomes. They need not work directly together and, in many instances, have quite different ultimate policy goals and likely disdain each other."). A Baptist might not know the morally questionable nature of the aid or, alternatively, might suspect something is amiss but refuse to investigate so as to avoid having to confront the contradiction. See Donald J. Kochan, Incumbent Landscapes, Disruptive Uses: Perspectives on Marijuana-Related Land Use Control, 3 TEX. A\&M J. ProP. L. 35, 54-55 (2016) ("The Baptists will look the other way as to the bootleggers' motives and remain willfully blind to the possible immoral acts that the bootleggers might perpetrate, because they know that without bootlegger funding in the legislative effort, the effort is less likely to succeed."). It may even be that a third-party "political entrepreneur" is coordinating the efforts of bootleggers and Baptists as a means of pursuing individual preferences. See Simmons et al., supra note 167, at 368 (positing that this third-party mediation is more likely than Baptists and bootleggers directly coordinating their efforts).

182. Yandle, Bootleggers in Retrospect, supra note 158, at 5. 
the Baptists' marginal cost and expands the range of possible goals the Baptist can pursue. ${ }^{183}$

\section{What's in it for the Bootlegger?}

The bootlegger is interested in little more than the bottom line. ${ }^{184}$ In most cases, that will mean an increase in profits, although the private rewards sought through the government can be non-monetary. ${ }^{185}$ What makes a bootlegger different from traditional rent-seekers is the desire to remain behind the scenes. ${ }^{186}$ As a result, some forms of rent-seeking will be unavailable to the bootlegger qua bootlegger that would be on the menu of any other rent-seeker.

A bootlegger is likely to have a broad rent-seeking agenda, looking for various ways to manipulate the levers of power for its own ends. In some situations-particularly those where public attention is minimal or entirely absent - the bootlegger will be able to operate in the open without the need to minimize its footprint. 187 That will, in turn, increase the bootlegger's effectiveness in maximizing its rent-seeking profits, since it need not temper its demands to avoid scrutiny. ${ }^{188}$ However, when the rents being sought arise in an area of government that attracts intense public interest or controversy, rent-seeking is less effective if conducted in the open. ${ }^{189}$ The reason is simple — the public would be outraged

183. Yandle \& Buck, supra note 148, at 188.

184. See Yandle, Bootleggers in Retrospect, supra note 158, at 5 ("[Bootleggers] are simply in it for the money."). It is possible, of course, that "some Bootleggers might be Baptists, and vice versa," Adler et al., supra note 153, at 320 , but the ultimate goals of the two groups are far enough apart that such a scenario will almost certainly be the exception, rather than the rule.

185. See Adler et al., supra note 153, at 321 (suggesting bootleggers also seek regulations decreasing competition).

186. Yandle, Bootleggers in Retrospect, supra note 158, at 5.

187. See Adler et al., supra note 153, at 322 (referencing the support the Sierra Club received openly from natural gas firms to support initiatives harmful to the coal industry).

188. Id.

189. See, e.g., id. at 322 ("Public health and environmental regulations may provide particularly fertile ground for Baptist-Bootlegger coalitions because it can be difficult to oppose health and environmental measures openly."). 
at open and obvious catering to the wishes of special interests. ${ }^{190}$ In those cases, a bootlegger may have to choose whether to act through a Baptist or not act at all. In other words, there are many situations where a bootlegger chooses between lower rent-seeking profits or none at all. The presence of a Baptist-the more vocal and convincing, the better-expands the range of rent-seeking opportunities for the bootlegger by providing public-interest justifications for the bootlegger's private goals. ${ }^{191}$

The symbiotic nature of these peculiar coalitions is explained in large part by the fact that neither side can achieve its goals without the skills of the other. ${ }^{192}$ Combining the organizational strength of the Baptists with the financial strength of the bootleggers reduces the marginal costs for both and widens the range of possible victories they can achieve. ${ }^{193}$ There is another reason why these improbable partnerships succeed, however. It is that their goals are different in important ways. The Baptist has broad goals, driven by lofty moral views of the ideal world.194 Details are not irrelevant, but they are an afterthought. The bootlegger cares little for the overall social purpose of the regulation, so long as the details lead to higher payoffs. ${ }^{195}$ The bootlegger will simply choose from the many options for achieving the Baptist's broad goals the route that offers the highest profits, and trust that the Baptist's zeal for the regulation will assure reasonable enforcement. ${ }^{196}$ Both sides will be content with the outcome.

190. $I d$.

191. See Yandle \& Buck, supra note 148, at 188 (lowering the costs for favor-seeking by shielding motives behind public interest motivations).

192. See Yandle, Bootleggers in Retrospect, supra note 158, at 7 ("[N]either well-varnished moral promptings nor unvarnished campaign contributions can do the job alone. It takes both.”).

193. Yandle \& Buck, supra note 148, at 188.

194. Yandle, Bootleggers in Retrospect, supra note 158, at 5.

195. See Adler et al., supra note 153, at 323 (opining that Bootleggers' interests may coincide with public welfare or may subvert it).

196. See Yandle, Bootleggers in Retrospect, supra note 158, at 5. It is for this reason that the original bootlegger and Baptist coalition succeeded. Baptists wanted fewer people to consume alcohol, a broad goal that can be achieved in a variety of ways. Id. One of those ways, at least in theory, is to curb the ability of individuals to obtain alcohol from suppliers. Id. Bootleggers already operate 
This raises another important question: if both parties are pleased with banning alcohol on Sunday, why stop there? Why not ban alcohol sales entirely? More broadly, what are the limits to the success of the coalition? The answer is that the limits are political. The combination of moral outrage and money is potent, but not all-powerful, and regulation is certain to be subject to increasing marginal costs and decreasing marginal benefits. ${ }^{197}$ The electorate will eventually reject even the most convincing Baptist argument if the costs rise high enough and the marginal benefits fall low enough. ${ }^{198}$ Moreover, successful regulation requires buy-in from the regulator, and regulators have their own incentives.

\section{What's in it for the Regulator?}

Much has been written about the incentives that regulators face. ${ }^{199}$ They certainly face pressures from many groups, each wanting regulations that add to the utility of group members, be that direct monetary benefit or some view of social welfare. ${ }^{200}$ Over time, it is possible that regulators develop specific policy

outside the regulatory regime, so they will gladly support restrictions on the purchase of alcohol. Id. Baptists demand enforcement of the regulatory restrictions and rest easy, content in the belief that fewer people are consuming alcohol on Sunday. Id.

197. See infra note 342 and accompanying text (explaining how marginal benefit can become a negative in the context of information).

198. This follows from the foundational economic principle that individuals are rational, that they care about increasing benefits and limiting costs to themselves. MaXwell L. Stearns \& TodD J. Zywicki, Public Choice Concepts AND ApPlications In LAW 7-10 (2009). Public choice economics teaches that individuals maintain that motivation when acting in groups, but that group outcomes will not necessarily reflect the same rationality. Id. at 10-20. However, even under public choice analysis, costs and benefits remain relevant, and a high-cost or low-benefit policy will be disfavored.

199. See generally George Stigler, The Theory of Economic Regulation, 2 BELL J. ECON. \& MGMT. SCI. 3 (1971) (elaborating on the capture theory of regulation to explain which groups will be successful in capture); Sam Peltzman, Toward a More General Theory of Regulation, 19 J.L. \& ECON. 211, 213 (1976) (arguing that regulators can serve the public interest as they balance the demands of competing interest groups).

200. See Stigler, supra note 199, at 3 ("Regulation may be actively sought by an industry, or it may be thrust upon it."). 
preferences dictated by one or more interest groups. ${ }^{201}$ Even taking those preferences as a given, however, regulators must still act subject to certain external constraints, both in terms of process and substance. Understanding the role regulators play in the bootlegger and Baptist scenario requires an appreciation of those constraints.

Optimization models are a standard analytical tool of economics, typically considering either maximization or minimization goals. ${ }^{202}$ For example, consumers are typically thought of as maximizing utility subject to a budget constraint, ${ }^{203}$ but they can also be thought of as minimizing costs, subject to a minimum level of utility. Regulators are no different, and they are often portrayed by public choice analysis as maximizing their annual budgets through strategies ${ }^{204}$ with such interesting names

201. For a helpful example of how public choice economists view the process by which regulators are "captured," see MANCUR OLSON, THE RISE AND DECLINE of Nations: Economic Growth, Stagflation, AND Social Rigidities (1982). Early capture theories of regulation were proposed in MARVER H. BERNSTEIN, REgulating Business By IndePEndent Commission (1955), and GabRiel KolKo, The Triumph of Conservatism: A Reinterpretation of American History, 1900-1916 (1963). The theory was later augmented by a formal economic model that viewed the regulatory process as an auction between interest groups. Stigler, supra note 199, at 3 . Many make the mistake of assuming that regulatory capture is a danger only from the regulated industry. See, e.g., Prentice \& Spence, supra note 136, at 1847 (citing Mancur Olson to support the explication that business groups exert disproportionate influence over the policy process). However, capture merely requires a strong interest in controlling regulatory outcomes and that incentive exists not only in industry but a host of other organizations that stand to gain power, prestige, or profit if they can nudge regulatory outcomes in a particular direction.

202. For a description of "optimization models" for non-experts, see 1 KATTA G. Murty, Optimization Models for Decision-Making: Junior Level 9-13 (2003), http://www-personal.umich.edu/ murty/books/opti_model/junior-1.pdf.

203. See BUTLER ET AL., supra note 148, at 7-8 (listing wealth, time, laws of nature, knowledge, and choices as important constraints to individual opportunity).

204. Regulators have various choices when it comes to regulation, including formal and informal rulemaking, adjudication, and more. Morriss et. al., have argued that regulators continue to experiment with new tools, including regulation by litigation and regulation by negotiation. Andrew P. Morriss, Bruce Yandle, \& Andrew Dorchak, Choosing How to Regulate, 29 HARV. EnVTL. L. REV. 179, 182 (2005) (finding regulation-by-negotiation and regulation-by-litigation similar as compared to regulation-by-rulemaking because of the instituted procedural differences). More recently, regulators have been experimenting with 
as the Washington Monument Strategy. ${ }^{205}$ They can also be thought of as seeking to minimize costs, subject to a set of baseline goals. Importantly, the costs that regulators seek to minimize are their own costs, not the costs imposed on consumers and producers by the regulations. ${ }^{206}$ The minimization effort is also not limited to resource costs, but includes the cost of mistakes, the cost of enforcement, and political costs. ${ }^{207}$

Minimizing mistakes can be thought of in a political sense but also in terms of process. Regulators would like to avoid blowback from those lawmakers who determine agency funding. ${ }^{208}$ More mistakes typically lead to a more frustrated electorate, which leads to increasingly irritated lawmakers and, potentially, lower budgets as a result. ${ }^{209}$ Regulators may also wish to avoid mistakes for the same reason that the rest of us do-they do not wish to experience the disutility of failure. ${ }^{210}$ Whether for political or personal

regulation by "Dear Colleague" Letter. See Letter from Russlynn Ali, Assistant Sec'y for Civil Rights, U.S. Dep't of Educ. Office for Civil Rights, to Title IX Coordinators 2 (Apr. 4, 2011) (providing "guidance to provide recipients with the information to assist them in meeting their obligations ... and implementing regulations that [DOE] enforce"). Although fascinating, how regulators choose between these strategies is outside of the focus of this research.

205. Irina D. Manta, Privatizing Trademarks, 51 ARIZ. L. REV. 381, 394 (2009). The Washington Monument Strategy has reference to the actions of the National Park Service in the wake of a budget cut in the mid-1980s. Rather than attempt to cut waste within the bureaucracy, or even to shutter under-utilized national parks, the Park Service chose to close one of the most-visited sites in the country, the Washington Monument. Those attempting to gain tickets to ride the elevator to the top of the Monument were informed that it was closed due to budget cuts and were encouraged to visit their Members of Congressconveniently located nearby-and express disapproval that their vacation plans had been disrupted. The funding was restored in short order. Government agencies are said to be employing the Washington Monument Strategy when they choose a "solution" most likely to inconvenience the public and lead for calls to raise the agency budget.

206. See Morriss et al., supra note 204, at 210-11 (positing that only when imposing such costs on consumers or industries generates political costs will the agency consider those costs).

207. Yandle, Bootleggers and Baptists, supra note 6, at 13.

208. See id. at 16 (referencing empirical studies that suggest the FTC, for example, has been less likely to take action against firms in districts represented by congressmen who sit on the committee controlling the FTC's budget).

209. Id. at 13 .

210. Id. 
reasons, avoidance of mistakes will lead regulators to minimize the number of points where decisions must be made and discretion exercised. ${ }^{211}$

Regulators will also seek to minimize the amount of resources that must be expended to enforce the regulations. ${ }^{212}$ By doing so, the agency can claim to be achieving the specific goal while freeing up more resources for other goals that the agency is pursuing. The easiest way to do this is to promulgate "simple rules requiring uniform behavior" because those rules will make compliance easier-and violations less likely_but also because detection of any rule-breaking will be easier. ${ }^{213}$

Finally, regulators seek to minimize the negative impact on voters and industries important to powerful legislators. ${ }^{214}$ Regulators are motivated to behave in "politically prudent" ways by protecting those constituencies. ${ }^{215}$ Unlike the first two cost-minimization efforts, which require adoption of simple regulations, this final constraint will not inherently lead to simple rules. It will, however, lead to rules favoring those interests that legislators prefer. ${ }^{216}$ Bootleggers will have contributed monetarily to those legislators, and the Baptists' moral suasion will have impressed some legislators or, at the very least, convinced cynical legislators that appearing to favor Baptists' interest will positively influence electoral results. ${ }^{217}$

211. Id.

212. Id.

213. Id. Rules requiring uniform behavior are also more likely to be viewed as inherently fair, even though that perception is likely to be false, given the various complex and heterogeneous relationships that the regulations will have to govern. Id.

214. See, e.g., Morriss et al., supra note 204, at 211 (discussing the political costs of regulations that impose regressive taxes).

215. See Yandle, Bootleggers and Baptists, supra note 6, at 13 (suggesting legislators are unlikely to be supportive of regulators who harm the industries and workers in that legislator's district).

216. See Morriss et al., supra note 204, at 193 ("Accountability to the political branches is not perfect, of course, but agencies must take the views of members of Congress and the President into account in shaping regulations.").

217. See Yandle, Bootleggers in Retrospect, supra note 158, at 7 (speculating that the canny politician could make a "Baptist" appeal to "enable voters to feel better by endorsing socially accepted value" while pocketing bootlegger money). 
Regulators will therefore implement rules that will benefit both Baptists and bootleggers, so long as there is a simple rule that does both. ${ }^{218}$ Importantly, though, nothing in the Bootlegger and Baptist Theory requires the view that regulators are just cynical mercenaries, selling out their preferences to the legislator that yells the loudest or the lobbyist that talks the smoothest. ${ }^{219}$ The influence of the Baptist allows the regulator to credibly claim-and believe - that there are actual solutions at hand for the problems the agency was ostensibly created to solve. ${ }^{220}$ When the solutions fail, as they inevitably do-whether the result of quackery or bootlegging ${ }^{221}$ — the complexity of the system being regulated gives the regulator plenty of cover for claiming good faith in developing the rule in the first place.

The conditions that lead to quackery can also impact a regulator's incentives. Regulators' preference for simplicity and easy enforcement must be balanced against the demands of legislators even in the best of times, but in the wake of a crisis the pressures on regulators increase just as dramatically on regulators as on legislators. ${ }^{222}$ Some actions taken in the wake of a crisis may be mere regulator negligence-regulatory quackery—but a savvy

218. Many people argue that the regulatory state is destroying the American economy under the weight of a complex regulatory regime. See, e.g., Todd Zywicki, Rent-Seeking, Crony Capitalism, and the Crony Constitution, 23 SuP. CT. Econ. REV. 77 (2015) (arguing that in the current "crony capitalist" system rent-seeking is turned on its head and the government creates and distributes rents to itself and favored interests). However, this argument need not be contradictory to the claims presented above. Instead, the combined weight of an excess amount of simple rules can still result in great complexity.

219. Nothing in the Bootleggers and Baptist Theory completely discounts this possibility either, so that mercenary regulators are entirely possible and plausible within the theory. See generally Yandle, Bootleggers and Baptists, supra note 6, at 13 (introducing the Bootleggers and Baptist theory).

220. See Yandle, Bootleggers in Retrospect, supra note 158, at 5 ("Baptists point to the moral high ground and give vital and vocal endorsement of laudable public benefits promised by a desired regulation.").

221. With mere quackery, failure is largely guaranteed, given the haphazard way in which the policy is chosen. Supra Part II.C. With bootlegging, on the other hand, failure is likely because the policy has been specifically crafted to achieve goals outside of those perceived by the public.

222. See Bainbridge, supra note 5, at 1785 (arguing that when bubbles burst, investigators turning up excesses and abuses in the regulatory system creates populist pressure for new regulation). 
bootlegger would realize the opportunity presented by the crisis. ${ }^{223}$ As the Baptists whip the public and legislators into an atmosphere where inaction is simply not feasible, bootleggers will be working to assure that their interests are advanced.224 The crisis atmosphere will increase the regulator's willingness to accept any solution that ostensibly meets the Baptists' goals. ${ }^{225}$ The bootlegger, having a detailed understanding of its own interests and the ways in which the system can be manipulated for its benefit, can provide the regulator with simple and easy-to-enforce rules that will be snatched up by the regulator who needs a quick fix. ${ }^{226}$

\section{B. How to Spot a Bootlegger}

When the interests of bootlegger, Baptist, and regulator all coincide, laws will be passed and rules will be promulgated that allow the Baptist to declare an initial victory while adding to the bottom line of the bootlegger. The question remains: how can we know when regulatory policy is the result of bootlegging? The task is difficult because the bootlegger must remain in the shadows. ${ }^{227}$ Following the money will typically be inconclusive, because political contributions are made for a variety of reasons ${ }^{228}$ and teasing out precise motivations is often a fool's errand.

223. After all, in the midst of a crisis politicians will feel immense pressure to craft some form of response, even if that response does not directly address the problems that arise. $I d$. at 1785-86.

224. See, e.g., id. at 1786 ("Because such periods typically involve an upswing in populist anger and accompanying intense public pressure for action, they offer 'windows of opportunity' to well-positioned policy entrepreneurs to market their preferred, ready-made solutions when there is little time for reflective deliberation.").

225. Id.

226. Id.

227. Yandle \& Buck, supra note 148, at 188.

228. Indeed, as the reach of government expands, it is likely that political contributions-both in terms of total dollar amounts and the number and breadth of those contributing-will continue to rise. After all, it is the ability of government to bestow favors that draws rent-seeking behavior, not the other way around. See generally Tullock, supra note 160 (introducing the concept of rentseeking whereby well-organized interests pursue government favors). 
Baptists are usually quite easy to spot-they aggressively court public opinion and explain the moral necessity of the proposed change. ${ }^{229}$ It is not a significant exaggeration to say that the difficulty with Baptists is not identifying them, but rather in finding a way to tune them out. The same cannot be said of bootleggers, since they must try to avoid public scrutiny if they wish to maximize the likelihood of achieving their goals. ${ }^{230}$ Because they will be doing their best to avoid identification, how can we identify them? By building a circumstantial case that includes identifying failed policies that persist in a way that suggest the presence of a bootlegger and identifying the actual results of the policy and those that benefit from the policy's unstated goals. ${ }^{231}$

Given any social problem and a desire to fix it, there are numerous possible paths that can be chosen; ${ }^{232}$ how do government agents choose a path? An idealistic view of regulation posits that legislators and regulators will make their choice after long consultation with all relevant parties, exhaustive economic analysis, and careful consideration of all social and cultural impacts. $^{233}$ It is possible, as explained by the quackery hypothesis, that the choice was made in haphazard fashion in the wake of a crisis and with little consideration for whether it will work. ${ }^{234}$ However, it is also possible that the choice was made to reward

229. See Yandle \& Buck, supra note 148, at 194 (drawing the comparison of environmental activists to the Baptist for the "moralistic attitude they adopt").

230. See, e.g., Adler et al., supra note 153, at 360 (depicting states and bondholders as bootleggers operating in the shadows of e-cigarette regulations because of the needed revenue provided by traditional cigarette smokers).

231. Yandle argues that government "rarely accomplish[es] its stated goals at lowest costs" and that "regulators seem dedicated to choosing the highest-cost approach they can find." Yandle, Bootleggers and Baptists, supra note 6, at 13. One need not adopt that position, however, to appreciate that government rarely achieves its goals fully or in a cost-effective manner.

232. See Morriss et al., supra note 204, at 179-83 (listing the pros and cons of forms of regulating, and attempting to provide a theory for explaining agency choice on the method of regulation).

233. See id. at 214-16 (explaining the public interest theory of regulation). The theory accepts that decisionmakers are flawed and, as a result, there will be mistakes and even "deliberate acts of chicanery," $i d$. at 215 , but the final decision is presumed to be the result of this form of careful deliberation.

234. Supra Part II.C. 
those who were most persuasive in their rent-seeking. ${ }^{235}$ This latter possibility is often overlooked, but it provides an alternative answer to the conclusion that government is merely inept. It is not inept; rather, it is pursuing non-obvious goals, and by identifying which individuals or entities would benefit financially from the rules, we can identify potential bootleggers.

At least two words of caution are appropriate at this juncture. First, following the necessity of separating correlation from causation, evidence that a benefit is derived from legislative or regulatory action is not proof that the benefitted party is a bootlegger. That evidence introduces the possibility that the benefitted party is a bootlegger, but it is not conclusive. In other words, benefitting from a failed policy is a necessary but not sufficient condition. Second, in attempting to identify those parties that benefit from seemingly failed regulation, it is unwise to discount those individuals or entities who bear some portion of the regulatory burden. Although it appears contradictory that burdens can be benefits, regulations are often sought by those to be regulated because the regulations can provide benefits in the form of barriers to competition, standardized risk, and so on. ${ }^{236}$

\section{Bootleggers or Quacks?}

With an understanding of the Bootlegger and Baptist Theory, we can return to the question of whether Dodd-Frank's regulation of hedge funds is mere regulatory quackery or more interestingand sinister-bootlegging. Bainbridge identifies anticorporate populists as the motivating force behind Dodd-Frank's corporate governance quackery, ${ }^{237}$ and hedge funds faced similar populist

235. See Morriss et al., supra note 204, at 220 (explaining Stigler's economic theory of regulation as viewing the legislative process as an auction where the highest bidder dictates the contents of legislation).

236. See Yandle, Bootleggers and Baptists, supra note 6, at 12-13 (providing real-life scenarios where regulated firms sought regulations for the individual benefits they provided, the observation of which led to his Bootlegger and Baptist theory).

237. Bainbridge, supra note 5, at 1784-86. An important question, which we leave for another day, is whether those "policy entrepreneurs," id. at 1786, are more properly defined as bootleggers or, perhaps, the vocal Baptists giving cover 
anger in the wake of the financial crisis. ${ }^{238}$ These populists may be nothing more than committed-if incorrect-idealists who believe that corporations are detrimental to society. If so, and if they acted alone, then hedge fund regulation is mere negligence-regulatory quackery. ${ }^{239}$ However, it is possible that anti-corporate populists or other, less noticeable groups, understood the importance of using a crisis for advancing previously obstructed goals and manipulated Dodd-Frank to extract additional benefits for themselves. ${ }^{240}$ If so, then the menace is bootlegging, rather than quackery.

The rest of this Article will be devoted to answering this question by applying the tools of public choice to Dodd-Frank's hedge fund rules. After analyzing the nature of hedge funds in the context of the recent financial crisis, Dodd-Frank regulations appear as destined for failure as the quackery of corporate governance changes identified by Romano in Sarbanes-Oxley and Bainbridge in Dodd-Frank. The inevitable failure, however, seems poised to benefit certain groups in a way that seems more than coincidental, indicating the presence of bootlegging.

\section{What is a Hedge Fund?}

Beyond the fact that hedge funds are involved in financial markets, most people might not know exactly what a hedge fund is and does. Media and political mentions of hedge funds are likely

for more careful bootleggers.

238. See Walter Hamilton, Tina Susman \& Tom Petruno, A Strong Message to Wall Street; The 150-Year Sentence for Bernard Madoff Reflects a Harsher Stance Against Financial Crime. Victims Cheer, L.A. TIMEs, June 30, 2009, at A1 (attributing Madoff's harsh sentence to the public outrage directed at hedge funds amidst public scandals and the financial crisis).

239. Title IV of Dodd-Frank authorized the SEC to require the registration of hedge funds and adopt controversial disclosure and reporting obligations. Wulf A. Kaal, Hedge Fund Manager Registration, 50 SAN Diego L. REv. 243, 250-51 (2013).

240. See Bainbridge, supra note 5, at 1786 ("Because such periods typically involve an upswing in populist anger and accompanying intense public pressure for action, they offer 'windows of opportunity to well-positioned policy entrepreneurs to market their preferred, ready-made solutions when there is little time for reflective deliberation.”). 
to be long on invective and short on details, possibly because the speaker knows as little about hedge funds as the average American. Nor is it a shameful thing to have difficulty elaborating on what a hedge fund is, considering hedge funds tend to be more easily defined by what they are not than what they are.

There are as many investment strategies as there are hedge funds, maybe more; what unifies them is that they have historically all been exempt from the Investment Company Act (ICA).241 Being exempt means having significant competitive advantages over those investment companies that must register under the ICA. For example, an exempt entity avoids registration requirements, which lowers their overall cost of doing business. An exempt entity would also avoid restrictions on who it can employ in management positions, which means it has flexibility in hiring the best people for the job.

More important than flexibility in their human resources departments, hedge funds also enjoy greater flexibility in financial markets. They avoid the Investment Company Act's restrictions on the types of investment and mandated procedures for changing direction. For example, unlike traditional investment firms, hedge funds have historically been allowed to purchase securities on margin, engage in joint purchases, and sell securities short. ${ }^{242}$ Hedge funds could also change their investment strategies at will, a freedom not enjoyed by investment companies that must register under the ICA. ${ }^{243}$

This increased flexibility opens the door for hedge funds to achieve greater returns for their investors, but those returns are achieved through exposure to additional risk. Because of that risk, and because there is uncertainty associated with new investment options, hedge funds must offer higher profits to entice investors to accept hedge funds as a legitimate substitute investment option. As mentioned, being exempt from the ICA grants some

241. 15 U.S.C. $\S \S 80 a-1$ to a-64 (2012).

242. See id. § 80a-12 (making it unlawful for a registered investment company to purchase any security on margin, engage in joint trading accounts, or short sale a security).

243. See id. $\S 80$ a-13 (regulating the ability of registered investment companies to change their investment policies as those policies deviate from the recited policies in the registration statement of such investment companies). 
opportunities for achieving higher profits, but some hedge funds have sought higher returns by making bold moves as influential shareholders in major corporations. ${ }^{244}$

When hedge funds are successful, the resulting business decisions might be beneficial, or they might be harmful. Only in the long run will it be evident which, and the hedge fund will likely have taken its gains and moved on to the next source of profit. A skeptic could argue that there are only a finite number of easy-profit changes to be made and that, once those changes have been enacted, additional pressures for high profits in the short term are likely to do more harm than good. On the other hand, it is hardly an easy task to identify the point at which innovation becomes harmful. Aversion to change can be motivated as much by fear or a desire to protect some preferred group of investors or management as by a concern for the overall health of the market or individual businesses. It is for that reason that hedge-fund regulation under Dodd-Frank is potentially harmful as a protectionist endeavor.

\section{The Great Recession and the Birth of Dodd-Frank}

In the wake of the financial meltdown of 2008-2009, there was tremendous pressure on policymakers to take action to make sure that the experience was never repeated. ${ }^{245}$ That pressure was

244. See, e.g., Marcel Kahan \& Edward B. Rock, Hedge Funds in Corporate Governance and Corporate Control, 155 U. PA. L. REV. 1021, 1024-25 (2007) (discussing specific instances in which hedge funds have exerted corporate control and played a role in corporate governance). Most hedge funds do not pursue this type of bold shareholder action, but the impact of the minority that do is enough to make directors nervous about the impact of activist hedge funds on their companies. See id. at 1026 ("The Wall Street Journal, the newspaper of record for executives, bankers, and investment professionals, calls hedge funds the "new leader' on the 'list of bogeymen haunting the corporate bedroom."').

245. See Bainbridge, supra note 5, at 1782-83 (discussing the "boom-bust-regulate" pattern following market tumult and the outrage prompting Congress to regulate in such cases). One possible response is that without knowing the exact causes of the financial collapse-a tall order when financial markets and the economy, as a whole, are incredibly complex-there is little reason to suspect that any solution will be able to achieve the goal of stabilizing markets. That is, however, somewhat beside the point, in that politicians feel pressure to do something in the wake of a crisis and their reliance 
substantiated in the form of Dodd-Frank, in part, because of a report issued by the U.S. Department of the Treasury. ${ }^{246}$ The ultimate form of Dodd-Frank was, no doubt, influenced by more than the Treasury Report, and it is certain that special interests took the now famous (or infamous) advice of former White House Chief of Staff Rahm Emmanuel: "never let a crisis go to waste."247 In fact, combining the complex subject matter of the legislationfinancial markets-and the timing of the legislation-in the wake of a severe economic crisis-it is unsurprising that the stated purposes of Dodd-Frank do not map perfectly onto the actual legislative contours of the Act. ${ }^{248}$

\section{A. Overarching Goals}

Notwithstanding some extraneous provisions, the clear sense of purpose inherent in Dodd-Frank is an attempt to stop a repeat of the financial crisis and subsequent meltdown. The stated aim of the legislation is:

on public good will for the continuation of their employment is almost certain to force them to craft a policy response. See id. at 1785-86 (discussing populist pressures in the wake of "when the bubble inevitably bursts"); Ribstein, supra note 45 , at 79 (examining interest group power when market crashes occur and the resulting populism considered by reformers).

246. See U.S. DeP'T of the Treasury, A New Foundation: Financial REGULATORY REFORM 2-4 (2009) (proposing reforms to promote supervision and regulation of firms and financial markets, protect consumers and investors, provide the government to manage financial turmoil, and raise standards and create cooperation on the international level).

247. See Gerald F. Sieb, In Crisis, Opportunity for Obama, WALL STREeT J. (Nov. 21, 2008), https://www.wsj.com/articles/SB122721278056345271 (last visited Nov. 3, 2017) (discussing President Obama's, and his team's, opportunity for reforms during the economic downturn in 2009) (on file with the Washington and Lee Law Review). For example, it is hard to see anything other than targeted rent-seeking as the justification for including a requirement that manufacturers identify minerals sourced from the Democratic Republic of Congo. See DoddFrank, Pub. L. No 111-203, § 1502, 124 Stat. 1376, 2213-18 (2010) (discussing the requirement that reports be provided for imported minerals and their relationship to violence in or near the Democratic Republic of Congo).

248. See, e.g., Todd Zywicki, The Rule of Law During Times of Economic Crisis (Geo. Mas. Univ. Legal Stud. Res. Paper Series, LS 15-09, 2015), http://ssrn.com/abstract=2651893 8-9 (arguing that economic crises lead to policy changes not entirely explained by the context of the crisis). 
To promote the financial stability of the United States by improving accountability and transparency in the financial system, to end "too big to fail", to protect the American taxpayer by ending bailouts, to protect consumers from abusive financial services practices, and for other purposes. ${ }^{249}$

This language is supported by the structure of Dodd-Frank, which reorganizes and consolidates oversight authority over financial markets, establishes new regulatory entities tasked with assuring financial stability, and creates an entirely new entity tasked with protecting consumers from abuse by financial markets. ${ }^{250}$ Even some who disagree vehemently with the specific choices made in enacting Dodd-Frank and the regulations since promulgated appear to concede the laudable aims of the legislation. ${ }^{251}$

\section{B. Criticism in the 111th Congress}

Hedge funds have been part of the debate about systemic risk and the stability of financial markets even before the collapse of 2008-2009, with criticisms often invoking the collapse of Long Term Capital Management in 1998 and its aftermath. Since then, other hedge funds have become infamous for similar practices and outcomes. ${ }^{252}$ It should come as no surprise, therefore, that hedge funds were included in a bill as massive and far-reaching as Dodd-

249. Dodd-Frank, 124 Stat. at 1376.

250. See 12 U.S.C. $§ \S 5321,5342$ (2012) (establishing the Financial Stability Oversight Council and Office of Financial Research); id. § 5491 (establishing the Bureau of Consumer Financial Protection).

251. See, e.g., Iain Murray, How Dodd-Frank Harms Main Street 1 (Nat'l Ctr. for Pol'y Analysis, Issue Brief No. 173, 2015) ("The reforms enshrined in [DoddFrank] ... were intended to protect Main Street and consumers from financial predation by Wall Street."); The Dodd-Frank Act Five Years Later: Are We More Stable? Before the H. Comm. on Fin. Serv., 114th Cong. 111 (2015) (statement of Todd Zywicki, Professor, George Mason University School of Law) ("An animating premise of [Dodd-Frank] was the belief that a primary source of financial instability was an inadequate consumer financial protection regime at the federal level.").

252. Magnetar and Amaranth, just to name two. For a more in-depth discussion, see Wulf A. Kaal, The Systematic Risk of Private Funds After the Dodd-Frank Act, 4 Mich. Bus. \& ENTREPRENEURIAL L. REV. 163 (2015) (discussing blame placed on the private fund industry for destabilizing the economy as a result of excessive risk). 
Frank. There were scholarly opinions regarding the need for reform, ${ }^{253}$ including some who rejected claims that hedge funds were to blame for the collapse. ${ }^{254}$ Out of those who actively spoke out about hedge funds, however, the majority appear to line up against hedge funds and in favor of regulation. ${ }^{255}$ Interestingly enough, however, political debate in the lead up to passage of Dodd-Frank is largely silent on hedge funds.

To be certain, hedge funds did become part of the debate, and in bipartisan fashion. For example, on January 29, 2009, Republican Senators Chuck Grassley and Carl Levin introduced S. 344, the Hedge Fund Transparency Act. ${ }^{256}$ In his remarks, Senator Grassley bemoaned the fact that hedge funds were allowed to operate under a "cloak of secrecy" and argued that the SEC required registration and disclosure from hedge funds "in order to protect the markets." 257 Notably, he failed to offer any specifics as to why hedge fund regulation and disclosure was essential to protect the market, but he did imply that hedge fund opposition to the measure was evidence of wrongdoing. ${ }^{258}$ Senator Levin, on the

253. Id.

254. See, e.g., Andrew W. Lo, Regulatory Reform in the Wake of the Financial Crisis of 2007-2008, 1 J. FIN. ECON. POL'Y 4, 16 (2009) ("[H]edge funds have played only a minor role in the current financial crisis, as evidenced by the lack of attention they have received in the government's recent bailout efforts."); Roberta Romano, Against Financial Regulation Harmonization: A Comment 3 (Yale L. \& Econ. Res. Paper, No. 414, 2010), https://papers.ssrn.com/sol3/papers.cfm? abstract_id=1697348 [hereinafter Romano, Against Financial Regulation Harmonization] ("[T] contributing factor in the recent financial panic.").

255. See Wulf A. Kaal, Hedge Fund Regulation via Basel III, 44 VAND. J. Transnat'L L. 389, 392-94 (2011) [hereinafter Kaal, Basel III] (describing the range of proposed regulatory solutions).

256. Hedge Fund Transparency Act, S. 344, 111th Cong. (2009).

257. 155 Cong. REC. S1058-59 (daily ed. Jan. 29, 2009) (statement of Sen. Grassley).

258. See id. at S1059 ("[T] his legislation hasn't had many friends. These funds don't want people to know what they do or who participates in them. ... Well, I think that is all the more reason to shed some light . . . on them to see what they are doing."). Senator Levin went one step further, implying wrongdoing by the simple fact that hedge funds had structured their business model according to the law itself, in order to make sure they were not covered by the regulations. Id. at S1059-60 (statement of Sen. Levin) ("By limiting the number of their beneficial owners and accepting funds only from investors of means, hedge funds have been able to... operate outside of the reach of the Securities and Exchange 
other hand, argued specifically that hedge funds had gotten so big that they posed a systemic risk, ${ }^{259}$ but size alone should not increase systemic risk.

It is also not clear whether the data supports Senator Levin's assertions. For example, while he cites a Congressional Research Study that puts the total market share of hedge funds at five percent of assets under management, ${ }^{260}$ he fails to mention that there are estimated to be somewhere between ten and fifteen thousand hedge funds, ${ }^{261}$ making the market impact of any individual hedge fund effectively zero. Moreover, the "secrecy" 262 of hedge funds that Senator Grassley criticizes exists between hedge funds, as each one attempts to adopt a unique strategy that will

Commission.").

259. See id. at S1060 ("The problem is that hedge funds have gotten so big and are so entrenched in U.S. financial markets that their actions can now significantly impact market prices, damage other market participants, and can even endanger the U.S. financial system and the economy as a whole."). Senator Levin also argued that there was a risk associated with pension funds investing in hedge funds, $i d$. at S1060 (discussing pension fund investment in hedge funds), but any discussion of pension funds is incomplete without a hard look at the reasons why pension funds are looking at hedge funds. For example, the Missouri State Employees Retirement System has allegedly invested thirty percent of its assets in hedge funds, but it is also only seventy-three percent funded with over three billion dollars in unfunded liabilities. ANDREW BIGGS, THE Funding STATUS of State AND Local Government Pensions in Missouri 15 (2015), http://bit.ly/2j9y1O7. If the pension fund is presumed to be obtaining only those returns offered by safe investments, like corporate bonds, the situation appears even more dire, with funding at only forty-five percent and an unfunded liability in excess of nine billion dollars. $I d$. at 18. It is the history of politicians choosing to underfund the pension plan, not anything done by the hedge funds-who merely offer the higher rate of return the pension plan needs to avoid insolvencywhich has led to what Senator Levin believes is an overinvestment in hedge funds.

260. See 155 Cong. REC. S1060 (daily ed. Jan. 29, 2009) (statement of Sen. Levin) (citing the study).

261. See Julia La Roche, Hedge Funds-There Are Too Many of Them and Most of Them Are Lousy, YAHoo! Fin. (May 7, 2016), http://finance.yahoo.com/news/are-there-too-many-hedge-funds-193953003.html (last visited Feb. 17, 2018) (suggesting that there are too many hedge funds and most are unable to perform adequately) (on file with the Washington and Lee Law Review).

262. See 155 Cong. REC. S1059 (daily ed. Jan. 29, 2009) (statement of Sen. Grassley) (discussing a bill Senator Grassley previously introduced to close a loophole which hedge funds have been able to utilize to operate in secrecy). 
give them an edge. The hedge fund industry is likely one of the most diversified in the financial markets, limiting the impact that any negative market even can have on the hedge fund industry, much less the financial markets, at large. ${ }^{263}$

Levin also argued that hedge fund compensation encouraged risk, ${ }^{264}$ but he gets the causal arrow the wrong way around. Hedge funds need higher returns to attract investors, and higher risk is the only way to achieve those returns, so the compensation package is structured to achieve the efficient level of risk. More to the point, the risk Senator Levin describes is borne by investors who have voluntarily joined this venture, a point he effectively concedes, ${ }^{265}$ yet then proceeds to tell the horror story of Long Term Capital Management. ${ }^{266}$ That story is convenient for both quacks and bootleggers, because government action-a bailoutprevented an actual conclusion to the story. Quacks like Senator Levin assure us that a bailout was necessary, and they are free to wax eloquent about the dangers of large hedge funds and the need for regulation precisely because he and others refuse to let market forces punish bad behavior. As a counter to his argument about size, more recent research has concluded that other large hedge fund failures, such as Amaranth, imposed no widespread burdens on the financial system. ${ }^{267}$

Senator Levin's final argument was that traditional banks had begun to form their own hedge funds and that the incestuous

263. See Joe Burns, Why Now Might Be The Right Time to Look At Hedge Funds, CNBC (June 20, 2017), https://www.cnbc.com/2017/06/19/why-now-mightbe-the-right-time-to-look-at-hedge-funds.html (last visited Feb. 17, 2018) (discussing the advantages that investors can gain by investing in hedge funds, including diversification) (on file with the Washington and Lee Law Review).

264. See 155 CONG. REC. S1060 (daily ed. Jan. 29, 2009) (statement of Sen. Levin) ("The compensation system employed by most hedge funds encourages that risk taking.").

265. See id. ("[I]f wealthy people want to take big risks with their money, all else being equal, they should be allowed to do so without the safeguards normally required for the general public.").

266. See id. (discussing the Federal Reserve's rescue of Long-Term Capital Management when the company began to falter while having a total market proposition of $\$ 1.3$ trillion).

267. See Kaal, Basel III, supra note 255, at 394-95 (suggesting that the collapse of large hedge funds did not cause systemic problems). 
relationship was potentially harmful. ${ }^{268}$ This is the only argument with teeth, yet, even if true, it would only support a rule that requires strict separation between traditional, regulated investment firms and the hedge funds that are operated under the same holding company. Dodd-Frank did include the Volcker Rule, ${ }^{269}$ which not only prohibited proprietary trading by banks, but also prohibited banks from "acquir[ing] or retain[ing] any equity, partnership, or other ownership interest in or sponsor[ing] a hedge fund or a private equity fund," 270 so nothing else should have been required, yet additional regulations were piled on.

This type of heavy-on-rhetoric, light-on-substance criticism of hedge funds continued throughout the 111th Congress, and in some unusual places. For example, hedge fund manager compensation is often in the form of carried interest, so taxation of carried interest became a popular subject and was raised during debates over entirely unrelated bills, such as: (1) the Children's Health Insurance Program Reauthorization Act of $2009 ; 271$ (2) the American Recovery and Reinvestment Act;272 (3) the Healthy, Hunger-Free Kids Act of 2010; ${ }^{273}$ and (4) the Federal Aviation

268. See 155 Cong. REC. S1060 (daily ed. Jan. 29, 2009) (statement of Sen. Levin)

Because of their ownership, their size and reach, their clientele, and the high-risk nature of their investments, the failure of hedge funds today can imperil not only their direct investors, but also the financial institutions that own them, that lent them money, or did business with them. From there, the effects can ripple through the markets and impact the entire economy.

269. See 12 U.S.C. $\S 1851$ (2012) ("Prohibitions on proprietary trading and certain relationships with hedge funds and private equity funds.").

270. Id. $\S 1851(\mathrm{a})(1)(\mathrm{B})$.

271. See 155 Cong. REC. S875 (daily ed. Jan. 27, 2009) (statement of Sen. Webb) (proposing to replace a tax on cigarettes with a higher tax on carried interest, "which is the compensation received by hedge fund managers").

272. See id. at S1625 (daily ed. Feb. 5, 2009) (statement of Sen. Reed) ("Our regulators need to have the tools and resources to get the job done. We have seen the problems with the unregulated hedge funds, private equity concerns, and the lack of enforcement by the Securities and Exchange Commission.").

273. See 156 Cong. REc. H7802 (daily ed. Dec. 1, 2010) (statement of Rep. Andrews) (arguing that a hedge fund manager who has lunch "at the priciest restaurant in Manhattan, maybe a $\$ 200$ or $\$ 300$ lunch" can afford a higher tax rate on carried interest). 
Administration Reauthorization. ${ }^{274}$ One of the most common claims was that because of the tax treatment of carried interest, hedge fund managers "who make more than $\$ 1$ billion a year now pay a lower effective tax rate than many teachers, nurses, firefighters, and police officers." 275

Hedge funds were mentioned in every manner of negative association, such as the legitimate reminder that Bernie Madoff was a hedge fund manager. ${ }^{276}$ Of course, there is no evidence that other hedge funds were operating similar schemes, but that was apparently no reason to avoid repetition of the "Ponzi scheme" accusation. ${ }^{277}$ There were accusations of hedge fund "gambling" in a speech opposing repeal of the estate tax, ${ }^{278}$ and other accusations of "manipulating markets." 279 In fact, they were a space-holder for anything perceived to be wrong with Wall Street; when criticizing

274. See id. at S1704 (daily ed. Mar. 18, 2010) (statement of Sen. Dorgan)

I suppose for somebody who makes $\$ 3.6$ billion in a year, which is $\$ 300$ million a month or $\$ 10$ million a day, and that person, who incidentally was the highest income earner running a hedge fund in 2008, that person not only got $\$ 10$ million a day in income but, because of the generosity of this Chamber and others, gets to pay a 15 -percent rate, one of the lowest income tax rates.

275. See id. at S7343 (daily ed. Sep. 22, 2010) (statement of Sen. Sanders) (discussing unfairness of the federal tax code); see also 155 CoNG. REC. H514 (daily ed. Jan. 26, 2009) (statement of Rep. Kucinich) ("The obscenity of hedge fund managers paying a tax rate of about 15 percent for most of a billion plus in income while some who clean our bedpans pay a higher tax rate . . . is: greed and a repudiation of the merit of hard work.").

276. See 155 Cong. REC. S1654 (daily ed. Feb. 5, 2009) (statement of Sen. Schumer) ("If you believe that, I have a hedge fund I would like you to invest in called Madoff Securities, LLC.").

277. See id. at H145 (daily ed. Jan. 9, 2009) (statement of Rep. Kucinich) ("We also have to address the issue of the fractional reserve system, which is how banks create money out of thin air. And then, as they do that, they've created the conditions where we've had this kind of Ponzi scheme collapsing, banks and the hedge funds working together.”).

278. See 156 CONG. REC. S6054 (daily ed. July 21, 2010) (statement of Sen. Sanders) ("Do you remember those hedge fund managers on Wall Street who made $\$ 1$ billion a year or several billion a year? They are going to benefit. Those are the guys-the people who drove us into the recession, who made huge amounts of money gambling on Wall Street.").

279. See 155 CONG. REC. S3359 (daily ed. Mar. 18, 2009) (statement of Sen. Harkin) (referring to Americans' view of "hedge fund hotshots" as manipulating markets and becoming further prosperous as a result). 
taxpayer bailouts of Wall Street, the plan was described as a "massive transfer of wealth from the American people to the hedge funds on Wall Street,"280 even though hedge funds make up a tiny fraction of our capital markets. They were portrayed as completely indifferent to any negative impacts on individuals in the economy ${ }^{281}$ and even as a likely source of future financial bubbles. ${ }^{282}$

The accusations got even more bizarre. Hedge funds were accused of massive tax avoidance. ${ }^{283}$ They were accused of being a big part of the problem with for-profit education. ${ }^{284}$ They were accused of bankrupting Chrysler just for insisting on their rights as secured creditors. ${ }^{285}$ They were even used as an excuse to oppose cap-and-trade as a solution to global climate change, because hedge funds would simply find a way to profit off the system. ${ }^{286}$

280. Id. at H3753 (daily ed. Mar. 24, 2009) (statement of Rep. Sherman) (arguing that because Wall Street takes six percent of the risk and fifty percent of the profits under plans to bail out Wall Street, wealth is transferred from the American people to hedge funds).

281. See id. at S9651 (daily ed. Sep. 22, 2009) (statement of Sen. Sanders) (stating that hedge fund managers do not care about disintegrating manufacturing, that millions have lost jobs, that small businesses cannot get credit, or about trying to build a productive economy).

282. See 156 Cong. REC. H8036 (daily ed. Dec. 7, 2010) (statement of Rep. Stearns) ("The Fed's QE2 plan could ... also create bubbles as hedge funds and other speculators borrow cheaply and make even bigger bets on stocks and commodities.").

283. See 155 Cong. REc. S2629 (daily ed. Mar. 2, 2009) (statement of Sen. Levin) (discussing how hedge funds utilize offshore entities, even though they are managed and controlled in the United States, resulting in an offloading of their tax burden on those entities that follow the rules).

284. See 156 Cong. REC. S8987 (daily ed. Dec. 14, 2010) (statement of Sen. Harkin) ("Another 33 for-profit education companies operating 65 more for-profit schools are at least partially owned by private equity investors or hedge funds. The result is that the vast majority of for-profit schools have prioritized growth over education in order to satisfy the demands of their investors.").

285. See 155 Cong. REC. H5047 (daily ed. Apr. 30, 2009) (statement of Rep. Miller) ("[B]ankruptcy will now be required only because of the greed of a few Wall Street hedge funds that held a portion of Chrysler's debt.”).

286. See id. at S7601 (daily ed. July 16, 2009) (statement of Sen. Dorgan) ("Such a [cap-and-trade] system is ripe for the biggest investment banks and the biggest hedge funds in the country to sink their teeth into these marketplaces and make massive amounts of money."). 
In discussing the financial collapse and mortgages, hedge funds were regularly featured, though usually with vague attribution of guilt, such as calling them part of some "dark money" cabal, ${ }^{287}$ implying that the mere purchase of risky mortgages made them responsible, ${ }^{288}$ or even that hedge funds-as speculatorswere hoping that people would default on their mortgages. ${ }^{289} \mathrm{On}$ this last claim, a certain story appeared in occasional speeches and debates, that a "hedge fund billionaire" had called up his friends at Goldman Sachs and asked them to put together a package of sub-prime mortgages that would likely default. ${ }^{290}$ The hedge fund manager would then sell the investments while betting against that package to make money. ${ }^{291}$ The story is obviously that of the Goldman Sachs ABACUS deal 292 and, while many of the general

287. See id. at S330 (daily ed. Jan. 13, 2009) (statement of Sen. Dorgan) ("We are not going to look at derivatives, we will not regulate derivatives, and we are not going to regulate hedge funds. We are willing to countenance a lot of dark money out there because we do not need to see it.")

288. See 156 CONG. REC. S4405 (daily ed. May 26, 2010) (statement of Sen. Dorgan) (suggesting that the sale of risky mortgages to hedge funds made everyone involved massive amounts of money but that this "cesspool of greed" was "steering this country into the ditch" and ended in the suffering of the American people). While it is true that the purchase of risky mortgages by hedge funds did contribute to mortgage companies being "awash in cash," id. at S141 (daily ed. Jan. 22, 2010) (statement of Sen. Dorgan), that no more makes hedge funds responsible for the collapse than those who eat at mafia-owned restaurants are responsible for the criminal acts of those who are, as a result, awash in cash to fund their illicit activities.

289. See 155 Cong. REC. H5141 (daily ed. May 5, 2009) (statement of Rep. Boccieri) ("We had hedge fund operators betting on the price of fuel going up; we had folks who were investing and betting on the price of food going up . . . and we had hedge funds that were betting that people would not be able to pay their mortgage.").

290. See 156 Cong. REC. H4665 (daily ed. June 22, 2010) (statement of Rep. Welch) (giving an example of the recklessness of Wall Street banks that contributed to the financial crisis); see also id. at H2647 (daily ed. Apr. 20, 2010) (statement of Rep. Stearns) (discussing Goldman Sachs putting together sub-prime mortgage packages); id. at H2803 (daily ed. Apr. 22, 2010) (statement of Rep. DeFazio) (same).

291. See id. at H4665 (daily ed. June 22, 2010) (statement of Rep. Welch) (discussing hedge fund betting against Goldman Sachs's ABACUS sub-prime mortgage packages without telling investors).

292. See Factbox: How Goldman's ABACUS deal worked, REUTERS (Apr. 16, 2010), https://www.reuters.com/article/us-goldmansachs-abacus-factbox/factboxhow-goldmans-abacus-deal-worked-idUSTRE63F5CZ20100416 (last visited Feb. 
parts of the story are accurate, Congressional Democrats hedged enough on the specifics to make it falsely appear: (1) almost exclusively the fault of the hedge fund; and (2) a harmful outcome that all hedge funds might pursue if not regulated. ${ }^{293}$

\section{From Criticizing to Legislating}

These and other criticisms of hedge funds found their way into Congressional hearings and, eventually, substantive legislation. For example, the Senate Committee on Homeland Security and Governmental Affairs considered banning investing by hedge funds in commodities markets ${ }^{294}$ and highlighted a report alleging that hedge fund Amaranth Advisors LLC manipulated natural gas markets in 2006. ${ }^{295}$ The Committee also held hearings on an alleged practice of hedge funds establishing themselves as foreign entities to avoid paying U.S. taxes, even though hedge fund managers and other officials were based in the U.S. ${ }^{296}$ In the debates leading up to the passage of the Helping Families Save Their Homes in Bankruptcy Act of 2009,297 it was alleged that hedge funds were partially to blame for the financial crisis, but only because institutional investors had been attracted to the higher returns yielded by riskier investments. ${ }^{298}$

17, 2018) (explaining how the ABACUS deal worked according to the SEC fraud complaint against Goldman Sachs) (on file with the Washington and Lee Law Review).

293. For example, Goldman Sachs chose to keep the identity of Paulson \& Co. from its investors, but there is no evidence that the idea was Paulson's. Most of the harms appear to have come from choices made by Goldman Sachs, not Paulson \& Co. See id. (explaining the SEC view of the ABACUS deal).

294. See S. REP. No. 111-360, at 27 (2010) (discussing "the impact of financial speculation by hedge funds as a factor in rising food and fuel costs").

295. See id. at 143 (discussing excessive speculation in the natural gas market).

296. See id. at 156-57, 159 (discussing how entities avoid U.S. taxes by going offshore and proposals to eliminate tax havens and abuses).

297. Pub. L. No. 111-22, 123 Stat. 1632 (2009).

298. See H.R. REP. No. 111-19, at 17 (2009) (discussing the impact of the housing crisis on the mortgage industry). Even if true, this claim would support a ban on all high-risk investments and doing so would place an effective ceiling on U.S. economic development and innovation. 
The primary activity on hedge fund regulation during the 111th Congress, however, was Dodd-Frank, which was cobbled together from multiple bills originating in the House and Senate and regulates hedge funds in four primary ways. First, it requires registration of hedge fund advisors by eliminating the private advisor exemption under the Investment Advisors Act of 1940.299 Second, it requires advisors to maintain detailed information regarding assets under management, use of leverage and investment positions held by the fund, trading practices, counterparty risk exposure, valuation policies and practices, and any side arrangements, and grants the SEC the power to mandate regular reports and audit hedge funds. ${ }^{300}$ These collection and reporting requirements have the potential to impose significant costs on hedge funds, ${ }^{301}$ and yet the most substantial impact of these requirements might be that they raise the curtain on what had previously been closely guarded secrets regarding investment strategies.

The third way Dodd-Frank regulates hedge funds is by changing the rules governing hedge fund investors. The definition of an "accredited investor" under Regulation D will now exclude the value of the investor's primary residence, making it more difficult for an investor to qualify. ${ }^{302}$ Similarly, the definition of a "qualified client" will now include an adjustment for inflation, making it more difficult for investors to qualify. ${ }^{303}$ Finally, Dodd-

299. See 15 U.S.C. $§$ 80b-3(b) (2012) (abolishing the private advisor exemption). Although the general registration requirement kicks in only when the fund has more than $\$ 150$ million in assets under management, the SEC is also allowed to define "mid-sized" funds and require them to register, as well. As a practical matter, most hedge funds will have to register. Interestingly, DoddFrank exempts venture capital funds from the registration requirement, although the legislative text leaves open the question of what constitutes a venture capital fund, entrusting formulation of a definition to the SEC.

300. See id. $\S 80 \mathrm{~b}-4(\mathrm{~b})(3)$ (listing the types of required information that advisors must maintain).

301. But see Wulf A. Kaal, Private Fund Disclosures Under the Dodd-Frank Act, 9 Brook. J. CorP., Fin. \& CoM. L. 428 (2015) [hereinafter Kaal, Private Fund Disclosures] (describing survey results that indicate a low level of compliance costs).

302. See 17 C.F.R. $§ 230.501(a)$ (2017) (providing the definition of "accredited investor").

303. See id. $\S 275.205-3(d)(1)$ (providing the definition of "qualified client"). 
Frank regulates hedge funds by requiring internal compliance measures. Each hedge fund will now be required to implement compliance programs and hire a compliance officer. ${ }^{304}$ Some of these regulations might be seen as relatively innocuous, yet when combined, they have the potential to dramatically change the way hedge funds do business.

Among the sources of hedge fund material for Dodd-Frank were the Private Fund Investment Advisers Registration Act of 2009 ("House Bill") 305 in the House and the Restoring American Financial Stability Act of 2010 ("Senate Bill") 306 in the Senate. Both bills had been the subject of hearings in their respective houses.

\section{Action in the House}

The House Bill focused on registration, and the committee hearings seem to acknowledge some potential benefits of hedge funds as an alternative investment option, ${ }^{307}$ but they also emphasized "potential dangers for systemic risk and investor abuse."308 The SEC had been pushing for increased regulation of hedge funds since 2004, and had offered three justifications: (1) rapid growth in the industry; (2) ordinary investors were exposed through institutional investors; and (3) the number of fraud actions against hedge funds had increased. 309 These three justifications are at least regulatory quackery, for they are not symptoms of any actual danger. Hedge fund investors are presumed to be sophisticated enough to make decisions without the elaborate disclosures mandated by SEC regulations, and some

304. See id. $\S 275.206(4)-7$ (discussing these compliance requirements).

305. H.R. 3818, 111th Cong. (2009).

306. S. 3217, 111th Cong. (2009).

307. See H.R. REP. No. 111-686, at 6 (2010) ("[Hedge funds] offer the promise of increased market efficiency and job creation.") (emphasis added). It is not clear whether the authors of the Committee Report viewed this promise as real or illusory.

308. See id. (examining the potential benefits and dangers of hedge funds to provide background and explaining the need for legislation).

309. See id. (discussing the continuous lack of regulatory monitoring of hedge funds). 
of the increased return must be explained by hedge funds' lower costs because they are exempt. Institutional investors are sophisticated, which is why they manage the funds of ordinary investors and are bound by fiduciary duties, so ordinary investors are already protected. The final SEC justification makes very little sense, as it appears that the SEC is already responding to any events of fraud.

Rather than aiming to protect financial markets or investors, the real reason the SEC wanted to regulate hedge funds is that regulators felt uncomfortable not knowing what hedge funds were doing: "At various points in the financial crisis, de-leveraging by hedge funds contributed to the strain on financial markets. Since these funds were not required to register with regulators, however, the government lacked reliable, comprehensive data with which to assess this sort of market activity." 310 To be clear, hedge funds were reducing their risk by de-leveraging, ${ }^{311}$ yet regulators became concerned because they did not know the details surrounding hedge fund activity. The Committee Report notes that the bill required registration of hedge fund advisers and provision to the SEC of financial information on assets held but claims that the cost will be insignificant. ${ }^{312}$ As discussed below, ${ }^{313}$ there is reason to doubt that claim.

\section{Meanwhile, in the Senate}

Hearings on the Senate Bill present a conflicted view of hedge funds. In discussing the Volcker Rule, the Senate Report overlaps

310. U.S. DePt. of Treasury, Financial Regulatory Reform: A New FOUNDATION 37 (2009).

311. De-leveraging is the process of selling stocks that have been purchased with debt. After making those trades, the hedge fund is less burdened with debt which protects investors from loss. Sale of any security will place downward pressure on the market, but neither the Committee Report nor the white paper it cites provides any support for the contention that selling off highly leveraged positions placed any undue strain on the market that would not have otherwise existed. Doing so might explain why no hedge fund required a taxpayer bailout.

312. See H.R. REP. No. 111-686, at 12 (2010) (citing CBO estimates).

313. See infra Part VI.A (discussing Dodd-Frank's protection of investors). 
between banks and hedge funds are presented as problematic ${ }^{314}$ but later the Senate Report admits that "bank credit exposures to... hedge funds are very well secured," with banks holding collateral against " 219 percent of their exposure to hedge funds." 115 Even though the Committee had no evidence that hedge funds contributed to the financial crisis, the Senate Report still insisted that regulation of hedge funds was essential. ${ }^{316}$ Why? Because regulators did not feel comfortable not having any "precise data regarding the size and scope of hedge funds" 317 and because regulators feared that they might cause problems in the future. ${ }^{318}$

The Senate Bill's registration requirement was supported not only by former SEC Chairman Arthur Levitt ${ }^{319}$ but also by the

314. S. REP. No. 111-176, at 8-9 (2010) ("When losses from high-risk activities are significant, they can threaten the safety and soundness of individual firms and contribute to overall financial instability.").

315. See id. at 33 (citing a quarterly report issued by the Comptroller of the Currency).

316. See id. at 38 (discussing the importance of transparency in financial markets).

317. See id. (discussing effects of hedge funds being unregulated). During debate on final passage of Dodd-Frank, Representative Frank stated that the registration requirement would:

$[\mathrm{P}]$ rovide that all advisers that want to play in the capital markets must register and must disclose certain information so that that knowledge of what capital is doing, where it is and in what amounts will be known by our regulators. ... It should go a long way of having inside information in the role of the regulators of the United States as to what is at risk.

155 Cong. Rec. H14419 (daily ed. Dec. 9, 2009) (statement of Rep. Frank).

318. See S. REP. No. 111-176, at 38 (2010) ("While hedge funds are generally not thought to have caused the current financial crisis, information regarding their size, strategies, and positions could be crucial to regulatory attempts to deal with a future crisis.").

319. See Enhancing Investor Protection and the Regulation of Securities Markets-Part II Before the S. Comm. on Banking, Hous., and Urban Affairs, 111th Cong. 9 (2009) (statement of Mr. Arthur Levitt, Former Chairman, Securities and Exchange Commission) (testifying that he would "recommend placing hedge funds under SEC regulation in the context of their role as money managers and investment advisers"). 
AFL-CIO, ${ }^{320}$ CalPERS, ${ }^{321}$ the Investment Adviser Association, ${ }^{322}$ the Group of Thirty, ${ }^{323}$ the G-20, ${ }^{324}$ the Investor's Working Group, ${ }^{325}$ and the Congressional Oversight Panel. ${ }^{326}$ That this coalition included domestic and international regulators, along with a trade association for those already burdened by SEC regulation, is not surprising, ${ }^{327}$ but the coalition supporting regulation also included hedge fund industry groups, such as the Coalition of Private Investment Companies, ${ }^{328}$ the Alternative

320. See Enhancing Investor Protection and the Regulation of Securities Markets-Part I Before the S. Comm. on Banking, Hous., and Urban Affairs, 111th Cong. 19 (2009) (statement of Mr. Damon Silvers, Associate General Counsel, AFL-CIO) (testifying in support of a "broad, flexible jurisdiction that allow[s] the [SEC] to follow changing financial market practices").

321. See Regulating Hedge Funds and Other Private Investment Pools Before the Subcomm. on Sec., Ins., and Inv. of the S. Comm. on Banking, Hous., and Urban Affairs, 111th Congress 78 (2009) (statement of Mr. Joseph Dear, Chief Investment Officer, California Public Employees' Retirement System) (discussing the importance of private fund registration).

322. See Enhancing Investor Protection and the Regulation of Securities Markets-Part II Before the S. Comm. on Banking, Hous., and Urban Affairs, 111th Cong. (2009) (statement of Mr. David Tittsworth, Executive Director and Executive Vice President, Investment Adviser Association) (discussing IAA support of centralized registration and regulation of hedge fund managers).

323. See Group of THIRTy, FinANCIAL REForm: A FrAMEWORK FOR FINANCIAL STABILITY 30 (2009) (recommending registration of managers of private pools of capital based on size with some exemptions).

324. See G20 Working Group 1, Enhancing Sound REgulation AND STRENGTHENING TRANSPARENCY 30 (2009) (proposing a framework which would require hedge funds to register with and provide certain data to regulators).

325. See Investor's Working Group, U.S. Financial Regulatory Reform: AN INVESTOR'S PERSPECTIVE 5 (2009) (suggesting that regulatory gaps be filled by requiring registration of hedge funds, among other things).

326. See Cong. Oversight Panel, Special Report on Regulatory Reform 4 (2009) (discussing recommendations for the regulation of financial institutions).

327. A regulator seeking to expand the size and scope of the regulatory state is unsurprising, although not necessarily evidence of anything more than regulatory quackery. The support of activist investors like the AFL-CIO, CalPERS, and the Investors Working Group-created by the Council of Institutional Investors-looks more like bootleggers wanting to impose new regulatory burdens on the hedge funds who compete with them for control of various corporations. Finally, groups like the Investment Adviser Association represent investment advisers who already labor under the SEC's burdensome regulation, and are engaged in naked bootlegging by seeking to impose those same burdens on their direct competitors.

328. See S. REP. No. 111-176, at 38-39 (2010) 
Investment Management Association, ${ }^{329}$ and the Private Equity Council. 330

For some, the support of the regulated industry-often only portions of it-is an indication of the common sense of the proposal. To the contrary, such support is far more likely to be the result of existing market participants' attempting to erect barriers to further competition in order to increase market share and profits. Alternatively, perhaps these hedge funds are part of the fifty-five percent of hedge funds who voluntarily register with the SEC 331

Mr. James Chanos, Chairman of the Coalition of Private Investment Companies, ... testified that "private funds (or their advisers) should be required to register with the SEC. . . Registration will bring with it the ability of the SEC to conduct examinations and bring administrative proceedings against registered advisers, funds, and their personnel. The SEC also will have the ability to bring civil enforcement actions and to levy fines and penalties for violations.

The CPIC is described as "a coalition of private investment companies whose members and associates are diverse in both size and investment strategies, managing or advising an aggregate of over $\$ 100$ billion in assets." Coalition of Private Investment Companies, MARKETSWIKI, http://www.marketswiki.com/wiki/ Coalition_of_Private_Investment_Companies (last visited Mar. 3, 2018) (on file with the Washington and Lee Law Review).

329. See AIMA Supports US Regulatory Reform Proposals, ALTERnATIVE InV. MGMT. Ass'N (Jan. 23, 2009), https:/www.aima.org/article/aima-supports-usregulatory-reform-proposals.html (last visited Feb. 17, 2018) (announcing AIMA support for registration of hedge fund managers) (on file with the Washington and Lee Law Review). The AIMA website describes the group as "represent|ing] the alternative investment industry, with more than 1,800 corporate members in over 50 countries. AIMA's fund manager members collectively manage more than $\$ 1.8$ trillion in assets." About, Alternative INV. MGMT. Ass'N, https://www.aima.org/about.html (last visited Feb. 17, 2018) (on file with the Washington and Lee Law Review).

330. See Capital Markets Regulatory Reform: Strengthening Investor Protection, Enhancing Oversight of Private Pools of Capital, and Creating a National Insurance Office Before the U.S. H. Comm. on Fin. Serv., 111th Cong. 43 (2009) (statement of Mr. Douglas Lowenstein, President/CEO, Private Equity Council) (expressing that the PEC takes "no issue with requiring [private equity] fund managers to disclose... information to the SEC ..."). The PEC-now renamed the American Investment Council-is "an advocacy and resource organization established to develop and provide information about the private investment industry and its contributions to the long-term growth of the U.S. economy and retirement security of American workers." About the Council, AM. INV. CounCIL, http://www.investmentcouncil.org/the-council/about-the-council/ (last visited Feb. 17, 2018) (on file with the Washington and Lee Law Review).

331. See S. REP. No. 111-176, at 73 (2010) (discussing the amount of hedge 
and want their competitors to be similarly burdened by regulation. Of course, the fact that most hedge funds voluntarily register indicates that hedge fund investors are more than capable of demanding registration if they wish.

The Senate Bill also included hedge fund reporting requirements out of an alleged desire for openness and transparency. ${ }^{332}$ These provisions were supported by the same coalition of regulators and industry groups. ${ }^{333}$ The reports that the SEC would be authorized to mandate were to be kept confidential, exempt from Freedom of Information Act requests, ${ }^{334}$ but they would still impose financial burdens as hedge funds would be required to gather, maintain, and regularly transmit the data. More importantly, once the data is collected in one format, the likelihood of it being inadvertently revealed or intentionally stolen increases significantly.

Both the House and Senate Bills impose real burdens on hedge funds. The sponsors identify a host of scary bogeymen as justification for the regulations, yet their arguments boil down to a fear of the future and a desire for more government control. ${ }^{335}$

funds that have already voluntarily registered with the SEC).

332. See Enhancing Investor Protection and the Regulation of Securities Markets-Part I Before the S. Comm. on Banking, Hous., and Urban Affairs, 111th Cong. 89 (2009) (statement of Mr. Paul Schott Stevens, President and CEO, Investment Company Institute) ("[T]he Capital Markets Regulator should require nonpublic reporting of information, such as investment positions and strategies, that could bear on systemic risk and adversely impact other market participants."); Enhancing Investor Protection and the Regulation of Securities Markets-Part II Before the S. Comm. on Banking, Hous., and Urban Affairs, 111th Cong. 164 (2009) (statement of Mr. Richard Ketchum, Chairman and CEO, Financial Industry Regulatory Association) ("The absence of transparency about hedge funds and their investment positions is a concern.").

333. See S. ReP. No. 111-176, at 73-74 (2010) (noting Senate hearing statements and testimony regarding industry group and regulator support for registration and oversight).

334. See id. at 74 (discussing Section 404 of the Senate's bill requiring private fund records be confidential).

335. See H.R. REP. No. 111-19, at 17-18 (2009)

Attracted by high returns, institutional investors, such as pension funds and university endowments, are placing more of their money in hedge funds. And, as hedge funds invested in the risky subprime mortgage market, some high-profile funds incurred major losses, and several have filed for bankruptcy. As a result, "rank-and-file workers, 
Regulation is necessary because, otherwise, how will regulators know what private individuals are doing with their money? The lack of any identifiable problem to be solved makes these regulatory efforts look like quackery, at the very least, or even bootlegging.

\section{Who is Dodd-Frank Protecting?}

Given the legislative history of Dodd-Frank, it is difficult to conclude that Dodd-Frank's regulation of hedge funds is likely to yield positive outcomes, but perhaps we are being too hasty. It may be worth considering that, perhaps, the sponsors were merely inarticulate in describing its benefits. Perhaps the current business practices of hedge funds are harmful in ways as yet unidentified. As discussed above, ${ }^{336}$ the primary concerns of DoddFrank were consumer protection and avoidance of systemic risk. Taking the criticisms of hedge funds at face value, hedge fund business practices might be concerning, as hedge funds are known for short-selling, purchasing on margin, high levels of risk, and levels of secrecy that could raise red flags regarding potentially fraudulent activity, insider trading, etc. Hedge funds might also be more likely to pursue short-term profits at the expense of the long-term stability of the businesses hedge funds invest in.

Against these potential claims of risks imposed by hedge funds and regulation under Dodd-Frank are two alternative arguments. First, that the concerns about hedge funds are illusory, that hedge funds simply do not pose the level of risk asserted by critics. ${ }^{337}$ Second, that even if critics are correct, the particular form of regulation chosen by the authors of Dodd-Frank and the SEC are ill-suited to eliminate or even mitigate the risk. ${ }^{338}$

retirees, and others may be unwittingly exposed to hedge fund losses."

(quoting Mark Jickling \& Alison A. RaAB, Cong. Research Serv., RL33746, HEDGE FUND FAILURES 2 (2006)).

336. See supra Part V.A (discussing the overarching goals of Dodd-Frank legislation).

337. See Romano, Against Financial Regulation Harmonization, supra note 254 , at 3 ("[T]here is an absence of evidence pointing to hedge funds as a contributing factor in the recent financial panic.").

338. See Antti Petajisto, Hedge Funds After Dodd-Frank, N.Y.U. STERN (July 


\section{A. Investors}

The first and most obvious group that might stand to lose because of the business practices of hedge funds are those investors who entrust their limited investment capital to hedge fund managers and their innovative investment strategies. ${ }^{339}$ Without transparency, investors might not have enough information to properly judge the riskiness of their investments. Many of the traditional concerns that arise in principal/agent relationships arise in the context of hedge funds, such as information asymmetries that can lead managers to pursue their own ends rather than the ends of investors. Similar to the disclosure and registration requirements of the 1933 Securities Act and 1934 Securities Exchange Act, perhaps more information will lead to better investment decisions. ${ }^{340}$

Of course, the fact that some information is better than no information does not answer the question of what is the proper level of information. After all, information is almost certain to be subject to increasing marginal costs and decreasing marginal benefits. ${ }^{341}$ As the amount of information required increases, the likely benefits decrease and costs increase. ${ }^{342}$ Furthermore, the

19, 2010, 3:41 PM), http://w4.stern.nyu.edu/blogs/regulatingwallstreet/2010/07/ hedge-funds-after-doddfrank.html (last visited Feb. 17, 2018) (discussing the broad implications of the passage of Dodd-Frank) (on file with the Washington and Lee Law Review).

339. As an interesting legislative note, the 111th Congress saw a bill entitled the "Investor Protection Act of 2009," but the Committee Report mentioned hedge funds only twice. On page 52, it mentioned that hedge funds were among the victims of Bernie Madoff. H.R. REP. No. 111-687, at 52 (2010). It also mentioned hedge funds on page 53, in the title of a report previously sent to the SEC about the Madoff scandal. Id. at 53.

340. This benefit may be overstated, however, as shareholders will have diverse ways of obtaining the type of information that is required by the 1933 and 1934 Acts, and now by Dodd-Frank. Moreover, it is difficult to see how disclosure to the SEC, rather than directly to investors, helps those investors make important decisions.

341. See supra Part III.A.2 (noting how the value of further regulation decreases as more of it is implemented).

342. In fact, it is possible for the marginal benefit to be negative after a given point. As but one example, even water will overload the human body and cause death if enough is consumed. This is easily seen with information, as information overload makes it impossible to process even the most useful information. 
increase in cost is likely to follow a non-linear path, potentially increasing geometrically or exponentially along some range. Even conceding benefits to be gained from increased disclosures, the exact value of those disclosures is unclear and there are likely to be high costs; at some point, the costs will overtake the benefits and render the disclosures harmful to both hedge funds, investors, and society. This is especially the case for the kind of sophisticated investor allowed to invest in hedge funds, ${ }^{343}$ who presumably already possesses the most important information or at least knows how to demand what information is lacking.

Wulf Kaal has begun to study the disclosure requirements and ask important questions about the burden imposed by them. ${ }^{344} \mathrm{His}$ initial results appear sound and indicate relatively low costs, ${ }^{345}$ so it is possible that the Dodd-Frank disclosure requirements are low enough that they are still largely beneficial. Then again, it is not clear that the type of sophisticated investor that invests in hedge funds requires the type of information provided by Dodd-Frank, so the benefits might be even lower than minimal costs, rendering the disclosures inefficient and harmful. Furthermore, Kaal's initial results are preliminary and have a relatively low response rate. ${ }^{346}$ It is possible that the responding hedge funds are a representative sample, but it is at least plausible that those funds who find the disclosure requirements onerous and costly have less ability to respond to the survey, as their resources are occupied fulfilling the disclosure requirements. ${ }^{347}$

343. See Mark Jickling \& Alison A. RaAB, Cong. Research Serv., RL33746, HEDGE Fund FAILURES 1 (2006) ("[Hedge fund investors] are presumed to be capable of understanding the risks and bearing the losses of such investment.").

344. See Kaal, Private Fund Disclosures, supra note 301, at 429 ("Private fund advisers have traditionally opposed enhanced transparency of the funds they manage, arguing that the mandatory private fund disclosure requirements in Form PF could inappropriately burden the private fund industry.").

345. See id. at 428 ("The key findings of this study indicate that the majority of private fund advisers responding to the survey incurred less than $\$ 10,000.00$ to prepare their initial data reporting to the SEC, with the cost of subsequent annual Form PF filings at about half the initial cost.").

346. See id. at 436 ("The overwhelming majority of the population did not participate in the survey.").

347. See id. at 1436-38 (identifying the possibility of selection bias in the study, and the possibility that the sample is not representative). 
In the end, it is far from clear that Dodd-Frank's disclosure requirements are beneficial to investors. ${ }^{348}$ There are likely benefits, although their magnitude is uncertain. There are certainly costs, and while they may be small, the uncertain nature of the benefits makes it impossible to determine whether DoddFrank helps or hurts investors. Most of Dodd-Frank's remaining regulation of hedge funds does not implicate investor protection, ${ }^{349}$ so Dodd-Frank seems to provide only weak protection for investors.

\section{B. Public}

Perhaps the real benefit of Dodd-Frank's regulation of hedge funds is in its protection of the financial system, as a whole. By protecting the integrity of the financial system, reducing systemic risk, Dodd-Frank might protect both investors and the public, at large, from the catastrophic consequences of another financial meltdown. There are two significant problems, however, with this justification of hedge fund regulation under Dodd-Frank. First, it is anything but clear that hedge funds pose the type of systemic risk that led to the meltdown, ${ }^{350}$ especially when considering the impact of much larger financial entities like Lehman Brothers. Second, disclosure and registration requirements alone provide little hope for decreasing systemic risk. ${ }^{351}$

348. Dodd-Frank's redefinition of accredited investors and qualified clients might protect some investors, but only by making it harder for them to invest voluntarily with a hedge fund. It is therefore a protection that presumes a need for protection, a tautology.

349. See Kaal, Private Fund Disclosures, supra note 301, at 472 ("[T]he industry's concerns that mandatory private fund adviser registration and disclosure requirements could inappropriately burden investment advisers seem to be mostly unfounded.").

350. See Romano, Against Financial Regulation Harmonization, supra note 254 , at 3 ("[Hedge funds] play no part in the leading analyses of the causes of the crisis by prominent academics and journalists."); see also S. REP. 111-176, at 237 (2010) ("Hedge funds have not been identified as a cause of the financial crisis and investors in failed funds were not bailed out.").

351. See Romano, Against Financial Regulation Harmonization, supra note 254 , at 12 ("Disclosure may provide proprietary information to other hedge funds, and may have a further untoward consequence of increasing systemic risk if all 
Hedge funds did not fail in noticeably dramatic fashion during the last crisis, nor did they fail with relatively high frequency. 352 Similarly, the fact that hedge funds "manage only a small proportion of the investment universe, particularly as compared to banks' assets, and are far less leveraged than banks" 353 indicates that hedge funds should not be our primary concern. However, it is possible that, although only a small portion of the investment universe, the practices of hedge funds pose a risk far in excess of their size; they may punch above their weight, as it were, in disrupting financial markets. ${ }^{354}$ For example, hedge funds compete by offering above-market returns which, by necessity, means accepting above-market risks-pushing the envelope, as it were. ${ }^{355}$ For most small hedge funds, their size would keep them from creating systemic risk, but some large hedge funds could potentially add to systemic risk if their investment choices pushed too far into risky territory. ${ }^{356}$

Some specific ways in which hedge funds might be seen to contribute to systemic risk are by short selling, ${ }^{357}$ selling on

funds imitate the disclosed trading strategy of more profitable funds.").

352. See id. at 3 (noting that hedge funds were not the cause of the financial crisis, nor did the financial crisis necessarily cause hedge funds to shut down at a greater rate than they normally would).

353. Id. at 6 .

354. See id. ("High-risk, and contrarian financial bets produce[] extraordinary financial returns, bringing enhanced scrutiny to their activity.").

355. See id. ("Often lurking in the background of the increased scrutiny [is] the suspicion that the outsized returns were obtained by questionable means.").

356. See id. at 18 ("Individual countries can create systemic risk by not adequately regulating local institutions, specifically, hedge funds.").

357. See 155 Cong. REc. S3120 (daily ed. Mar. 16, 2009) (statement of Sen. Kaufman)

Everyone believes the SEC needs to put on the brakes and stop those who dump millions of shares they don't own to drive prices down. Abusive short selling amounts to gasoline on the fire for distressed stocks and distressed markets. Abusive short selling happens when traders and hedge funds sell stock shares they don't have and won't be able to deliver....

See id. at S3121 (statement of Sen. Isakson)

What happened was hedge funds and other traders coming in to cash in were taking the downward spiral of stocks and banks and financial institutions in the country and making money off the demise and the decline of those stocks, all because there was no protection so that they 
margin, taking high-risk positions, and pursuing short-term profits. Notice, however, that many of these practices have significant social benefits as well as costs. ${ }^{358}$ For example, while short selling can put downward pressure on the market and create incentives to exaggerate problems in the market-potentially destabilizing the market-short selling on legitimate and truthful information provides essential signals to the market, increasing the odds that assets are properly priced and deterring the formation of bubbles. ${ }^{359}$ Some scholars have argued that short-sellers are engaged in a practice that is essential to the health of markets, rather than being detrimental to them. ${ }^{360}$ The ability to sell short provides additional opportunities for investment profits, increasing the incentive to identify new information about those opportunities. ${ }^{361}$ More importantly, it provides incentives for investors to bet against bubbles when the available information indicates that prices are too high. 362

Similarly, the dominant paradigm teaches that short-term profit seeking is detrimental to businesses, and that it can translate to instability in the market. ${ }^{363}$ However, it is not clear that long-term profits are always preferable to short-term profits.

couldn't feed off a downward spiral. The uptick rule, as well explained by the Senator from Delaware, simply provides a cushion to discourage those who would exploit a dangerous and difficult market and make money at the expense of the American people.

358. See, e.g., Merritt B. Fox, Lawrence R. Glosten \& Paul C. Tetlock, Short Selling and the News: A Preliminary Report on an Empirical Study, 54 N.Y.L. SCH. L. REV. 645, 647 (2010) ("The free availability of short selling can improve share price accuracy.").

359. See id. ("Short selling can make prices better reflect already-existing information relevant to making such predictions when such information is disparately spread among all the potential traders in the market.").

360. See id. (explaining that short selling increases traders' incentives to evaluate new information and allows for more accurate future predictions).

361. See id. at 647-49 (suggesting that short selling increases the chances of seeing a profit).

362. See id. at 650-52 ("If a bubble begins to form with respect to an issuer, persons who trade on the basis of a rational evaluation of future cash flows will all be pessimists ... and bubbles would in turn be more likely to burst before growing too large.").

363. See Martin Lipton \& Steven A. Rosenblum, Election Contests in the Company's Proxy: An Idea Whose Time Has Not Come, 59 Bus. LAW. 67, 78 (2003) (discussing the different goals achieved by long or short-term profit seeking). 
In some cases, pursuit of long-term goals can be more destructive of corporate value than short-term goals. ${ }^{364}$

Extensive purchases on margin and other risky behavior could increase the risk to investors, yet those investors are compensated for that risk in a competitive investment market. ${ }^{365}$ Actions in pursuit of additional profits both lead to the additional risk and are required to compensate for that risk. ${ }^{366}$ This might seem like a problem, but it is nothing more than an innovation designed to fill a gap in the investment universe left open by existing financial services firms. Without hedge funds, investors would invest at presumably lower risk but also lower returns.

More importantly, the relatively small market share enjoyed by hedge funds indicates that the risk they generate is unlikely to translate into systemic risk. ${ }^{367}$ The saga of Long Term Capital Management is used as a counterexample, but the imposition of government favors - in the form of a bailout-leave us with only ex post assurances by those who prefer greater regulation that the bailout was necessary. ${ }^{368}$ In the meantime, other large hedge fund failures, such as Amaranth, imposed no widespread burdens on the financial system. ${ }^{369}$ And, it bears mentioning that most hedge funds are not as large as Long Term Capital Management and

364. See, e.g., Jesse M. Fried, The Uneasy Case for Favoring Long-Term Shareholders, 124 YALE L.J. 1554, 1593 (2015) ("The use of bargain repurchases to benefit long-term shareholders can lead to 'costly contraction': managers seeking to buy back stock at a low price may give up economically valuable projets to fund the repurchase"); Id. at 1607 ("Managers serving long-term shareholders may increase the size of the firm through the spread of overpriced equity, even though the expansion may destroy economic value.”).

365. See Margarethe Rammerstorfer, Risk Acceptance and Regulatory Risk, 10 Competition \& REG. NETWORK InDUSTRIEs 235, 236 (2009) (noting that the level of risk is accounted for when pricing risky investments, indicating they will cost less than a more sound investment).

366. See supra Part IV (discussing the trade-off between riskier investments and the potential for greater profit).

367. See supra Part IV.B (noting that increased size is unlikely to increase the chances of systemic risk).

368. See supra Part IV.B (noting that Long Term Capital Management and Amaranth were used by quacks and bootleggers).

369. See Romano, Against Financial Regulation Harmonization, supra note 254, at 3 ("The collapse of the large hedge fund, Amaranth, during the 2007-08 crisis did not spark contagion in financial markets.”). 
Amaranth. It is, therefore, far from clear that hedge funds pose enough systemic risk to justify the costs of regulation.

Even conceding the existence of systemic risk, however, it is far from clear that Dodd-Frank's regulatory regime can minimize that risk in any way. Just as disclosure and registration requirements provide little protection to investors without meaningful enforcement power ${ }^{370}$ - to say nothing of the need to define the criteria for intervention-those requirements also provide little protection to the system as a whole. The best that can be said is that Congress imposed the new requirements because it had no idea how to properly regulate hedge funds ${ }^{371}$ and, as a result, set up the current regime only to gather data in order to facilitate future regulation. However, it is also possible that, while seemingly ineffective to address Dodd-Frank's stated goals, the current regulatory regime furthers goals not clearly stated-the goals of financial bootleggers.

\section{Bootleggers in Dodd-Frank}

If Dodd-Frank's stated regulatory goals are unobtainable, it might just mean that quackery is at work. After all, Romano and Bainbridge have shown that its corporate governance regime is largely quackery. ${ }^{372}$ Then again, just as Romano and Bainbridge point out the special interests-policy entrepreneurs ${ }^{373}$ - who benefit from the corporate governance regulations, there are groups that stand to gain from Dodd-Frank's hedge fund

370. See id. at 12 ("Disclosure may provide proprietary information to other hedge funds, and may have a further untoward consequence of increasing systemic risk if all funds imitate the disclosed trading strategy of more profitable funds.").

371. See, e.g., 111 CoNG. REC. S1061 (daily ed., Jan. 29, 2009) (statement of Sen. Levin) (relating concerns by a law-professor witness at Congressional hearings that no one knows what role hedge funds played in the financial crisis).

372. See supra notes 4-6 and accompanying text (discussing claims that Dodd-Frank does not accomplish what it was meant to).

373. See Romano, Making of Quack Corporate Governance, supra note 5, at 1528 (noting that policy entrepreneurs are needed to help prevent future financial crises); Bainbridge, supra note 5, at 1816 ("Key policy entrepreneurs were able to hijack the legislative process to advance a long-standing political agenda.”). 
regulation. The existence of those groups and their involvement in the legislative and regulatory process indicate that there may be a separate, non-public set of goals and purposes for Dodd-Frank's hedge fund regulation, and that those goals are being met. ${ }^{374}$ In other words, those calling the shots may be bootleggers instead of quacks.

The minority members of the Senate Committee on Banking, Housing, and Urban Affairs provided a handy list of possible bootlegging reasons for the chosen regulatory regime. "It is likely that investors will treat SEC registration as an SEC seal of approval." 375 As a result, those hedge funds engaged in borderline-unethical behavior might be able to hide their shady practices behind the veneer of respectability that registration and disclosure provide. ${ }^{376}$ Similarly, given the SEC's inability to adequately monitor those entities and managers already being supervised, ${ }^{377}$ adding additional subjects of regulation could lead to even less stringent enforcement of SEC rules and allow marginal firms to get away with dubious business practices.

It is possible, if unlikely, that shady hedge funds are the bootleggers at work here; it would certainly fit nicely with the terminology. However, two other groups stand to gain significantly from the choice of regulatory regime: large financial institutions;

374. See Romano, Making of Quack Corporate Governance, supra note 5, at 1524 (insinuating opinions on policy change come with political motives).

375. See S. REP. 111-176, at 237 (2010) (stating minority views).

376. For example, Bernie Madoff reassured skeptical investors by reminding them that the SEC had inspected his firm. See SECS. AND ExCH. Comm'N OfFICE OF INVESTIGATIONS, INVESTIGATION OF FAILURE OF THE SEC TO UNCOVER BERNARD MAdOFF's PONZI SCHEME-PUBLIC VERSION 427 (2009), http://www.sec.gov/news/ studies/2009/oig-509.pdf ("In addition, private entities who conducted due diligence stated that Madoff represented to them that the SEC had examined his operations when they raised issues with him about his strategy and returns.").

377. Testimony by Mary Schapiro, Chairman of the Securities and Exchange Commission, before the Subcommittee on Financial Services and General Government of the House Committee on Appropriations (Mar. 17, 2010), http://www.sec.gov/news/testimony/2010/ts031710mls.htm (lsat visited Feb. 17, 2018) ("It is important to note, however, that even with an increase in the number of exams these additional resources will enable us to conduct, we anticipate examining only nine percent of SEC registered investment advisers and 17 percent of investment company complexes in FY2011.”) (on file with the Washington and Lee Law Review). 
and large hedge funds. Financial institutions might desire to see hedge funds regulated as a way of recapturing marginal investors who had diverted some or all of their investment capital away from traditional financial services firms to hedge funds. Larger hedge funds might also have seen Dodd-Frank as an opportunity to impose disclosure burdens that would be highly burdensome to smaller hedge fund start-ups, curbing competition within hedge funds and consolidating market power with the established players in the market.

\section{A. What Would Big Finance Gain?}

Compared to large financial services firms, hedge funds are typically quite small. They are not without their advantages, however, possessing an ability to innovate that financial services firms lack. Those innovations and the ability to adopt them with haste have made hedge fund investments a substitute-albeit an imperfect one-for investments with traditional firms. Those innovations are also riskier, which will make hedge-fund investing too risky for some investors, but, to the extent that the profit differential is high enough, some investors choose hedge funds and provide competition for financial services firms. Competition is good for consumers but is not welcomed by firms who must constantly respond to competition or risk losing market share.

Large financial services firms would likely love to innovate but are prohibited from doing so by regulation. This innovation-stifling regulation comes in multiple forms, but two forms are most important for our purposes. First, there are simply some things that financial services firms are simply not allowed to do. To the extent that hedge funds can cross those lines, they can exploit opportunities for profit and pull investment dollars away. Second, and more importantly, the disclosures required of those financial services firms means that any successful innovation is likely to be adopted quickly by all other market participants, similar to a price-taker market. ${ }^{378}$ So, even where innovation is possible, the

378. Basic economic theory teaches that, in a price-taker market, each market player produces such a small portion of the total supply that no single player has any market power. These markets tend to exhibit zero economic profit and 
inability of financial services firms to capture the long-term benefits of that innovation means that there will be less innovation. Once again, a hedge fund that has no disclosure requirements can keep its innovations secret and enjoy additional profits for longer periods; investors seeking those additional profits will transfer some of their investment funds away from traditional firms and into hedge funds.

Dodd-Frank does little to prohibit any particular innovation by hedge funds, so there still exist areas into which hedge funds may venture that their larger, more established cousins may not. Certain profit centers might still be exploited by hedge funds, generally, as compared to financial services firms. By mandating the type of intense disclosure that Dodd-Frank requires, however, the regulations cut into hedge fund profit margins by the amount required to create and transmit the disclosures. These are not insignificant costs, particularly to smaller hedge funds. ${ }^{379}$

Possibly more important, however, is the disclosures themselves. While not a complete piercing of the secrecy previously enjoyed by hedge funds, preparing and disclosing the information to government means potentially hundreds or thousands of eyes will see proprietary information. There are numerous ways that information could find its way into competitors' hands. Even if current strategies are never disclosed, the increased likelihood of innovations being revealed means a reduction in the benefits to innovation and, as a result, fewer innovations. Over time, that will reduce the competitive advantage enjoyed by hedge funds. As the increased profits decline, marginal investors will return to the

relative uniformity between producers. Any innovation which shifts costs and increases profits is assumed to disperse quickly throughout the market, returning economic profits to zero rapidly. Importantly, this does not mean that no innovation takes place in price-taker markets, just that the incentives for innovating are less than they would be in a market where the economic profits to innovation were positive and durable. The financial services industry is not a price-taker market. However, the transparency in the market facilitated by (or, some might say, caused by) government disclosure requirements allows for rapid adoption of successful innovations by competitors, lessening the incentives to expend resources searching for profitable innovations.

379. See generally Paul G. Mahoney, Wasting A Crisis: Why SEcurities REGULATION FAILS (2015) (arguing that crisis legislation favors established and larger financial institutions over smaller and innovative ones because regulatory costs are differentially felt in the industry, directly impacting competition). 
relatively lower risk of established firms and established strategies.

To say that financial services firms would prefer to inhibit their competitors-even small ones-is not to disparage them but to admit that they are rational participants in a market heavily influenced by government regulators. However, that does not answer the question of why Dodd-Frank? One possible answer is that knowing that the torches and pitchforks were already out for them, and that they were unlikely to escape some additional regulatory burden, firms engaged in rent-seeking mode. Some commentators are convinced that the rent-seeking of the largest banks was successful, given the increased consolidation in banking since the financial collapse. ${ }^{380}$ Another avenue of rent-seeking by these firms could have been to take advantage of the skepticism with which many politicians and the public view hedge funds and, in a perverse way, level the playing field.

\section{B. Intra-Industry Conflict?}

We should not assume that only one set of bootleggers is in play here-or anywhere - as others might have similar incentives to curb competition. Specifically, one set of hedge funds might have an incentive to disadvantage another. Dodd-Frank imposes disclosure requirements that are more easily dispersed in a larger hedge fund than in a small one. Those requirements should therefore cause a greater decrease in profit margin for small hedge funds, driving many out of business and deterring many others from entering the market. Some of the resulting pool of unattached investment dollars will return to traditional investment vehicles, but some will redound to the benefit of those hedge funds that remain.

It is also possible that pure profit might not be the only driving force behind this conflict. In the search for increased investment

380. See Todd Zywicki, The Dodd-Frank Act Five Years Later: Are We Freer? (Geo. Mason U. Legal Stud. Res. Paper Series 15-54, 6-7 2015), https://papers.ssrn.com/sol3/papers.cfm?abstract_id=2704076 (arguing that the post-crisis period produces a codification and consolidation of government discretion, making it a long-term element of the economy and society). 
returns, some methods are more sustainable than others. Those strategies that have provided the foundation for larger and longer-lasting hedge funds may have been the low-hanging fruit, with newer upstarts venturing into increasingly risky waters. That increased risk provides an easy target for political opponents and established hedge funds may have seen a way to pare back the more adventurous elements in the industry in order to blunt those political attacks. It also adds to those established hedge funds' profit margin, so the political and the pecuniary might coincide nicely.

\section{Any Other Bootleggers Hiding?}

The very nature of bootleggers is that they stay in the shadows, hidden from view; identifying one says nothing about the existence of others. ${ }^{381}$ For example, pointing a finger of suspicion at large financial services firms does not let larger hedge funds off the hook, for both have incentives to push for Dodd-Frank-type regulations. There may also be other, less-obvious candidates for bootlegger status. As time passes and the full impact of DoddFrank is realized, more details may become clear regarding those who benefit from the apparently ill-conceived hedge fund regulations.

\section{Conclusion}

Hedge funds are more risky than traditional investment vehicles, but that is the nature of financial markets when greater returns are sought. Those who view hedge funds as a danger to the stability of our financial markets have not made their case, and they certainly have not provided evidence to support their claims. Moreover, even if not exaggerated, the risks of hedge funds are almost certainly not going to be remedied by Dodd-Frank's regulatory regime. It is possible-even plausible-that those designing the regulations are simply bad at what they do. After all,

381. See supra Part III.B (discussing the roll of, and difficulty in identifying, bootleggers). 
government regulation prior to the recent financial meltdown was poorly designed to deal with the risks that threatened the financial system. If mere negligence is to blame, then Dodd-Frank is the source of more than one form of regulatory quackery.

Unfortunately, there is an even less favorable possibility, that the regulations will operate as designed to advance less public-minded goals. Legislators and regulators may have acted innocently but in concert with financial bootleggers who stand to gain from requiring disclosure of competitors' trading practices, among other things. Imposing costs on competitors is a long-standing (if unfortunate) tradition in rent-seeking; requiring disclosures that take away a competitors' advantage at innovation would be a simple variation on a theme. Consistent with the bootlegger and Baptist theory, the regulations were championed publicly by those citing the moral and ethical benefits but the primary benefit will likely be those with financial motives. Moreover, the regulations are precisely the type predicted by Yandle-simple and easy to enforce. 